\title{
IN THE MIDDLE: BEING PORTUGUESE AND GAY IN THE WAKE OF THE EMANUEL JAQUES MURDER IN 1977 TORONTO
}

by

\author{
Michael Pereira \\ Bachelor of Arts in English, Ryerson University, 2015
}

\author{
A thesis presented to \\ Ryerson University and York University \\ in partial fulfillment of the \\ requirements for the degree of \\ Master of Arts \\ in the program of \\ Communication and Culture
}

Toronto, Ontario, Canada, 2018

(C) Michael Pereira, 2018 


\section{AUTHOR'S DECLARATION FOR ELECTRONIC SUBMISSION OF A THESIS}

I hereby declare that I am the sole author of this thesis. This is a true copy of the thesis, including any required final revisions, as accepted by my examiners.

I authorize Ryerson University to lend this thesis to other institutions or individuals for the purpose of scholarly research.

I further authorize Ryerson University to reproduce this thesis by photocopying or by other means, in total or in part, at the request of other institutions or individuals for the purpose of scholarly research.

I understand that my thesis may be made electronically available to the public. 


\title{
IN THE MIDDLE: BEING PORTUGUESE AND GAY IN THE WAKE OF THE EMANUEL JAQUES MURDER IN 1977 TORONTO \\ Michael Pereira, MA, 2018 \\ Communication and Culture \\ Ryerson University and York University
}

\begin{abstract}
This thesis revisits the murder of the 12-year-old Portuguese immigrant boy Emanuel Jaques in Toronto in 1977 and the cultural response it ignited through qualitative interviews with five Portuguese gay men who were coming of age around this moment. Homosexual men across the city were conflated with the men who murdered Jaques because of their sexualities and depicted as a threat to children by politicians, law officials, protestors, and members of the media. Young Portuguese gay men found themselves in between two sides of an intense moral panic yet their experiences had not previously been sought out and recorded. They recall facing a fear of self and of others following the murder, a questioning or rejection of their sexualities, and in one case, continuing guilt. These experiences are considered within a broader context of what it meant to be Portuguese and gay in the ' 70 s and ' 80 s in Toronto.
\end{abstract}




\section{Acknowledgements}

A work of this scope and ambition could never be completed without an unfaltering system of support behind me. I am indebted to my supervisor, Alan Sears, whose encouragement, guidance, and kindness consistently reassured and took this research much further than I could take it alone. I am extremely grateful to Darcey Callison and Jamin Pelkey, who have shared their time and expertise in helping me to imagine where this thesis could go as a student in their classrooms, and see it through to completion as attentive members on my committee. The safety and stability I could rely on throughout this process is due to the unconditional love extended to me by my partner Kevin John Siazon, my family, and my friends - and I thank them for it. I am also lucky to have been a part of a graduate program where student success is kept at its center by dedicated staff and faculty. Nonetheless, I will treasure my days commiserating (in couture) with my ComCult classmates on all of graduate school's confusions and challenges. I am excited to see where those I started this journey with will go next.

Last, but certainly not least, I must express my deepest thanks to the people who trusted me with their stories. Without them this thesis would not exist. It was a true pleasure to learn from each of them and expand my own understanding of the communities I am a part of. Their voices make space for Portuguese LGBTQ people in Toronto to find themselves in the history of this city and provide a fuller picture of both the Portuguese and LGBTQ2+ communities during their formative years in the ' 70 s and ' 80 s. 


\section{Table of Contents}

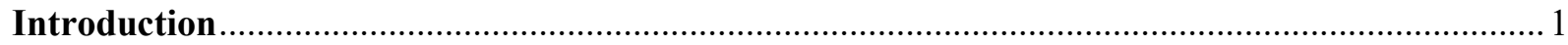

In the Middle

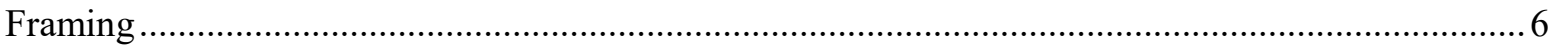

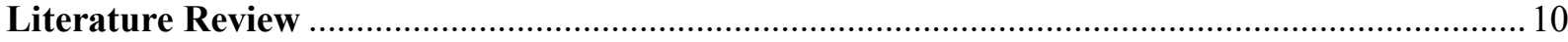

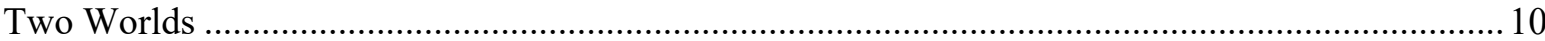

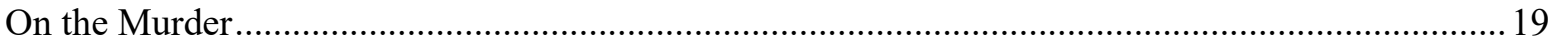

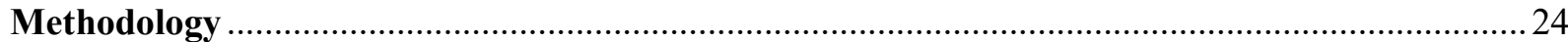

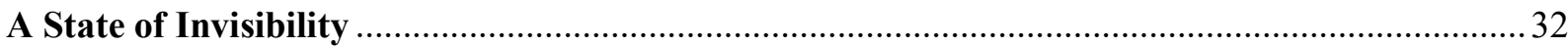

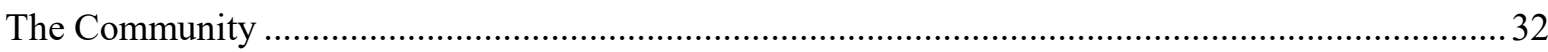

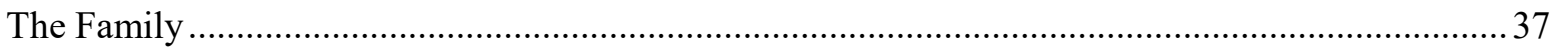

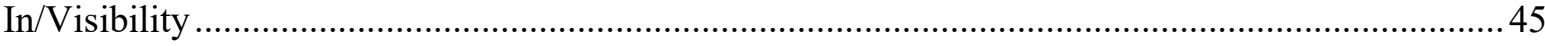

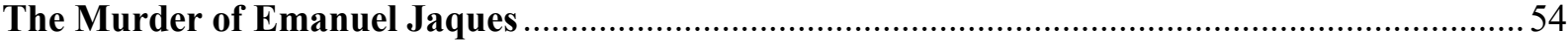

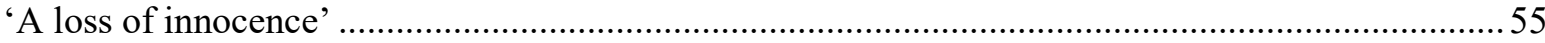

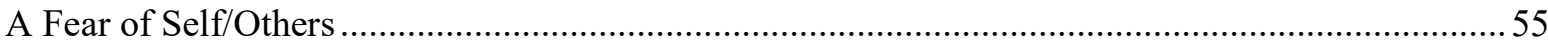

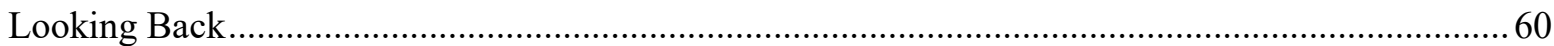

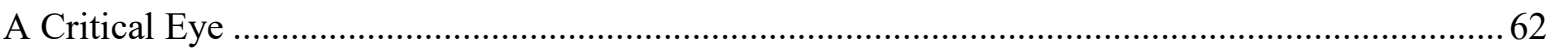

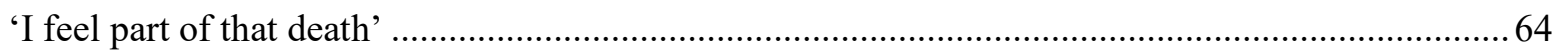

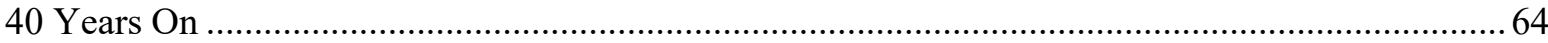

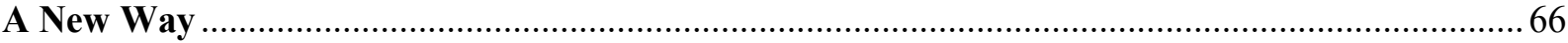

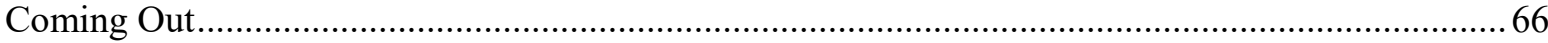

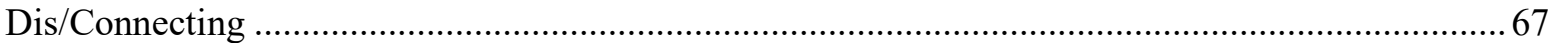

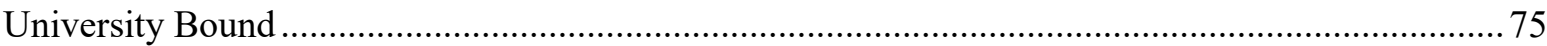

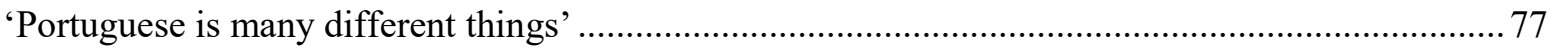

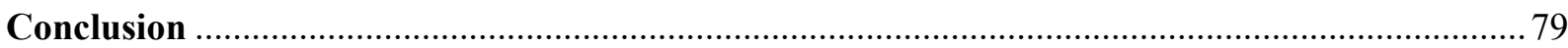

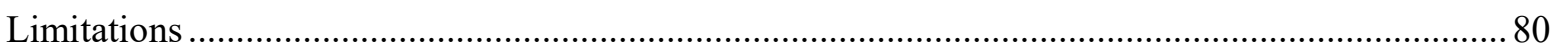

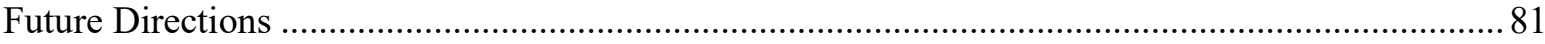

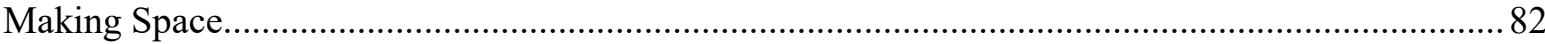

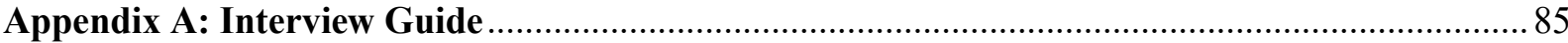

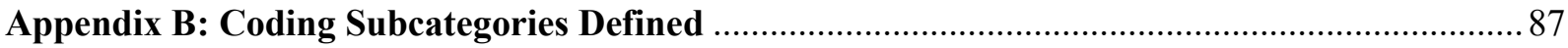

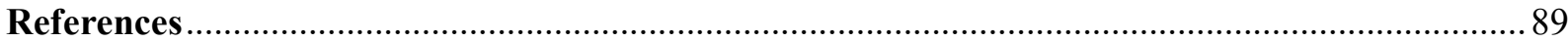




\section{Introduction}

\section{"A WARNING FOR ALL PARENTS"}

The Toronto Star. 2 August 1977. A2.

A child's bright eyes punctuate the bottom corner of The Toronto Star's front-page on Saturday, July 30th, 1977. The portrait of Emanuel Jaques sits under a short piece plainly titled, “Toronto boy, 12 missing." Jaques disappeared from the corner of Yonge and Dundas where he had been shining shoes with his brother and a friend two days earlier, offered $\$ 35$ an hour by a man claiming to need help moving cameras (Norris, 1977, July 30). "Shoeshine boy, 12, found slain," appears in the center of the Star's front-page on August 1st. Four men were charged in the murder. Three of them, it reads, worked at the Charlie's Angels body rub parlor on Yonge Street where Jaques' body was discovered (Thomas, 1977, August 1). "Victim of a sex orgy," appears under the masthead, italicized and underlined the next day: "Emanuel Jaques was drowned in a sink full of water after being held captive for 12 hours and made the victim of a homosexual orgy," Thomas and Graham reported (1977, August 2). The murder remained front-page news on each of Toronto's dailies for several days afterwards, approached from multiple angles by reporters, columnists, and readers inside each paper as well.

Soon after the news broke, residents from across the city took to the streets to voice their outrage and sadness. About 200 people from Jaques' Regent Park neighbourhood, a number of them young boys and girls themselves, marched from their homes to City Hall a day later. Demonstrators carried placards with forceful demands for action from politicians and law enforcement officials, including "KILL SEX PERVERTS," “CLOSE SIN SHOPS,” and, "GIVE US BACK CAPITAL PUNISHMENT," (Porambo, 1977, August 4). A climate of intense fear was also emerging, with messages like, "THE NEXT CHILD MAY BE YOURS," appearing 
among the crowd. The city's Portuguese immigrant population, of which Jaques and his family were a part of, internalized these messages and repeated them in their own demonstrations.

\section{"IT'S AS IF WE ALL LOST A SON HERE TODAY" The Toronto Star, 4 August 1977. A1.}

Over 4,000 mourners filled St. Agnes Church, spilling out onto the church steps and into Dundas Street as mass was prayed around Emanuel Jaques' small white casket. When asked why he had brought his sons to the funeral, one attendee explained, "It's part of their education in a city like this. They'd better know what goes on so they're not next. I've made them read every word in the newspapers about this" (Brazao, 1977, August 4). An estimated 15,000 people, organized by the Portuguese Radio Club, marched to City Hall and Queen's Park a few days later demanding the "clean-up" of the Yonge Street strip. Acting Mayor Arthur Eggleton appealed to protestors, "That the death of 12-year-old Emanuel Jaques not be in vain, we must see the cancer on Yonge Street will in fact be cleaned up," and promising, "We at City Council will use all the bylaws to clean up Yonge Street” (Rogers, 1977, August 9). It was not long until politicians ordered law enforcement actions in the "clean-up" of Yonge that led to the mass shuttering of adult businesses and massage parlours on the strip, similar to the one where Jaques' body was reported to be found (Brock 1998).

At the same time, gay activists noted that the heightened homophobia appearing as a result of the murder was misinformed and dangerous. George Hislop, president of the Community Homophile Association of Toronto (CHAT), explained, "This will smear the whole

of the gay community...There is more emphasis being put on the fact that this was a homosexual murder rather than just a murder" ("Homosexual backlash feared," 1977, August 3). Hislop, who had been called repeatedly by one of the suspects in the murder and had advised him to turn himself in, was subject to significant threats himself. The city's most prominent LGBTQ2+ 
(Lesbian, Gay, Bisexual, Trans, Queer, and Two-Spirit) community members were not the only targets of such sentiment. A petition boasting 1,000 names circulated outside St. Agnes Church among mourners at Jaques' funeral entitled, "STAMP OUT GAYS AND BODY RUBS," (Beddoes, 1977, August 5).

The Coalition for Gay Rights in Ontario organized a press conference in an attempt to counter such sentiment. Tom Warner, the coordinator for the Coalition, presented a letter the group had sent to Mayor David Crombie. It read, in part:

Some sections of the media...have created the impression that [Jaques'] slaying is somehow typical of homosexual activity. In so doing, they have transferred guilt on the entire gay community...Statements such as 'homosexual slaying' and 'homosexual orgy' result in indicting all homosexuals, thus making us co-accused. This assumes guilt by association and suggests that all gay people are at least indirectly responsible for the crime. (as cited in Beddoes, 1977, August 10; emphasis added)

Evidently, this was not sufficient. Globe and Mail columnist Dick Beddoes dismissed the coalition's argument that media portrayals of the murder fueled a conflation of Jaques' murderers and homosexuals across the city as "flatulent nonsense" (1977, August 10). Such a conflation continued to spread, reaching even the highest voices of authority in the Jaques case.

At the close of the ensuing trial, presiding Judge William Maloney used this conflation to question those fighting to see Human Rights Code protections extended to homosexuals during his sentencing of one of the suspects. He said:

There is one feature in your case that disturbs me more than a little. It is your acknowledged tendency to seek out ever-younger homosexual partners. I wonder how common that is among homosexuals. There are those who would seek legal protection for homosexuals in the Human Rights Code. You make me wonder if they are not misguided. (as cited in McCaskell, 2016, p. 84)

Ultimately, the assumption that homosexuals posed a threat to children was cemented as a dominant narrative in the discourse surrounding the murder. When adopted by the most authoritative voice in the case, the assumption was effectively bolstered with a veil of credibility. 
To be clear, the murder of Emanuel Jaques was an incredible tragedy that caused a family and innocent child immeasurable pain. No child should ever have their life cut short at the hands of an adult, and the horrifying abuse Emanuel Jaques suffered is absolutely reprehensible. This examination does not question any of these truths. Rather, it seeks to uncover a new way to understand a moment that has become a prominent part of the Portuguese community's collective memory in Toronto, and highlight the implications of the responses it inspired in the Portuguese community and in the city more broadly from previously unheard perspectives.

\section{In the Middle}

As a second-generation Portuguese-Canadian who has lived in Toronto all his life and is also queer, this historical moment proved compelling to me for several reasons. While learning about the Jaques murder for the first time in Anthony De Sa's novel Kicking the Sky (2013), I wondered how I might respond to such a public clash of the Portuguese and homosexual communities in Toronto if it were to happen today. I often feel that being Portuguese and queer, particularly in Toronto, is like fitting two incongruent parts together. I already keep a certain amount of distance between my Portuguese roots, mainly located through my family, and my queer life, so I wondered if seeing such negative attitudes about homosexualities so publicly voiced in response to a murder like this one would push me to conceal my sexuality even further. At the same time, I was thinking about those Portuguese LGBTQ folk who were present in 1977, and I found myself curious to find out how they experienced this moment. Unfortunately, I could find no existing research or publications that may help answer this question. My task became clear.

My thesis seeks out and records the voices of Portuguese gay men who lived in Toronto in the 1970s and ' 80 s to better understand how those in the middle of two emerging communities 
experienced their tumultuous convergence around the Jaques murder. In what follows, you will hear from Gilberto Prioste (60), Jorge da Costa (55), Adriano Aguiar (51), as well as Alex (49) and Trevor (48) (who both elected to use pseudonyms). Each of these men grew up in or around Toronto and continue to live in the city today. This work outlines the climate that these men faced prior to and after the murder as young homosexuals and sheds some light on how they have been able to respond to such a climate in a way that allows them to express their sexualities while navigating their connection to their Portuguese roots. My findings suggest that the climate surrounding homosexualities at this time pushed young Portuguese gay men into a state of invisibility where they faced numerous challenges developing and expressing their identities. The Jaques murder itself ignited fears and suspicions of oneself and of others that were specifically tied to participant's sexualities, and in one case, continuing guilt. To be sure, these individuals were not simply passive observers of their environments. In fact, they actively carved out ways to engage their sexualities, and in some cases, produce an identity where their sexualities and ethnicity could meaningfully coexist. Ultimately, this work begins to fill-in the space in the history of Toronto's Portuguese and LGBTQ2+ communities where these individuals exist. It provides useful insights for the study of these communities today, as well as the study of sexuality, ethnicity, and their intersections more broadly.

Participants in the work that follows are referred to as "gay" or "homosexual" with the knowledge that such labels cannot fully represent the fluid nature of sexuality, as well as all of the sexualities that fall between homosexual and heterosexual. When possible, "homosexualities" are used to refer to all sexualities that include an attraction to people of the same sex or gender. While limited, the terms "gay" or "homosexual" are most accurate in referencing a population of 
men who were in some way attracted to those of the same gender during a period when "queer" was not yet popularly used by those who might self-identify as such today.

\section{Framing}

I approach this research using the critical lens provided by social construction theorists. This theoretical framework frees the cultural environments under examination here from any misconceptions that would see them as entirely normal or inevitable and allows them to instead be understood as the product of specific conditions that meet at a particular moment in time. Social construction theorists posit that the reality of everyday life is not just something that exists independently of us, but is actively and consistently created in the ways we engage with one another in any particular environment (Berger \& Luckmann, 1966; Hacking, 1999). The language that we use to make sense of these constructions is itself constructed, with the associations we apply to particular words and the rules we create around their deployment defining our realities and those we imagine for others (Gergen, 1999). For example, to define someone as "poor" alters the ways they see themselves and the ways they are treated by family and friends, their employers, and the State. This particular examination calls upon us to consider how meanings associated with the label "gay" or "homosexual" in Toronto's Portuguese community in the ' 70 s and ' 80 s affected those who may have been labelled as such.

Another tenet of social construction that is useful for our purposes is the observation that our identities are also socially constructed. Berger and Luckmann (1966) have posed identity in a dialectical relationship with society where it is formed by social processes and relations. This is not to say that we forfeit all agency in fashioning ourselves. However, the societies in which we live define which identities may be openly expressed, accepted, and celebrated. Our identities are thus created and performed in relation to this learned knowledge - whether we choose to live in 
line with it, in resistance to it, or somewhere in between. The identities of the individuals at the center of this work must then be placed within the contexts they emerge from. Jung and Hecht's (2004) Communication Theory of Identity (CTI) is used here as an analytical framework to understand how the identities of participants were communicated within and informed by these contexts.

CTI understands identity as communicated through four interlaced frames: personal, enacted, relational, and communal (Jung and Hecht, 2004). Personal identity refers to an individual's self-concepts or self-images — essentially, how they think of themselves. This encapsulates traditional notions of identity as a purely internal phenomenon. Enacted identity encompasses an individual's performances or expressions of identity. Relational identity is made-up of four levels: (1) an individual develops their identity in part by internalizing how others view them. This is defined as ascribed relational identity; (2) an individual identifies themselves through their relationships with others, for example, as someone's partner or friend; (3) an individual identity exists in relation to other identities; and (4) a relationship itself can be a unit of identity. Communal identity transcends individuals altogether by considering how a group defines their identities collectively. Such an understanding of identity highlights the inconsistencies or frictions that may emerge between any of the four frames, understood by Jung and Hecht (2004) as identity gaps. In effect, CTI is particularly useful when studying how marginalized individuals negotiate and communicate "closetable identities," as illustrated by Faulkner and Hecht's (2011) application of it in their research with Jewish LGBTQ individuals. Like the population I am studying here, Faulkner and Hecht's participants are faced with significant parts of their identities that do not always fit together and may be emphasized or minimized in any particular context. 
This work will continue along the path set by other academics approaching this moment by recognizing the response to the Jaques murder as a "moral panic" (Ng, 1981; Kinsman, 1996; Newman, 2002; Brock, 2009). Ng was the first to classify it this way using Stan Cohen’s (1972) foundational work, and by doing so, they have pointed subsequent academics working through this incident towards a useful lens of understanding and a set of agents with particular roles and capacities to examine.

In Cohen's (1972) initial conception of the moral panic a number of different features are present. Moral panics are apparent when a "person or group of persons emerges to become defined as a threat to societal values and interests...in a stylized and stereotypical fashion by the mass media" (p. 9). These individuals are otherwise known as "folk devils," defined by Goode and Ben-Yehuda (1994) as, "The enemy, the source of the threat, selfish, evil wrongdoers who are responsible for the trouble" (p. 156). It is important to note that folk devils often do not actually pose the threat that they are accused of posing. They are, however, made to represent real fears and concerns held by those on the other side of a panic, and are thus implicated in its throws. Additionally, folk devils are not created indiscriminately, but are identified via fears or concerns that already exist but have laid latent in the populations moving the panic forward. A particular spark, like the murder of Emanuel Jaques, brings those fears to the surface (Goode \& Ben-Yehuda, 1994).

Those defined as folk devils may face significant social, political and cultural consequences during a moral panic. Goode and Ben-Yehuda (1994) have suggested that moral panics result in an increased level of hostility towards the chosen folk devils and a disproportionately high level of concern relative to the threat folk devils actually pose. This is because the supposedly "deviant” behaviour folk devils exhibit is seen as symptomatic of a 
larger threat to established value systems and ways of life (Garland, 2008). The deviant behaviour in question here was sex and sexualities that differed from the accepted norm - that between a heterosexual man and a heterosexual woman in a monogamous relationship. This panic specifically, Brock (2009) has argued, "helped to foster a climate that legitimated repressive police action against gay men," by defining them — as well as sex workers—as folk devils (p. 42). Homosexual men were faced with the notion that they posed a significant threat to children despite the fact that the vast majority of them had no hand in the murder of Emanuel Jaques and did not secretly harbour a sexual attraction to children. Portuguese gay men who remember the murder with some clarity recall grappling with, and even internalizing, this notion themselves. 


\section{Literature Review}

This work requires an understanding of both the Portuguese and the LGBTQ2+ communities around this moment, as well as a review of existing literature surrounding the murder and the response it inspired before it can move forward. This will give us a portrait of both worlds young Portuguese gay men stood in at this time and illustrate the space that this particularly research occupies. Research outlining challenges faced by the Portuguese in Toronto, as well as dominant attitudes about gender and family, will be useful later in this work when participants' voices that engage them are introduced. Recollections of this time from Toronto's LGBTQ2+ community are also necessary in understanding the fears faced by participants in the wake of the Jaques murder as part of a historical context and among others in the community.

\section{Two Worlds}

Up until the early-1950s, very few Portuguese settled in Canada. In 1953, 550 Portuguese men were recruited from the Portuguese mainland, Açores (an archipelago of nine islands in the mid-Atlantic), and Madeira (an archipelago of four islands off the northwest coast of Africa) to work as farm labourers and railway construction workers in Canada in a coordinated effort by Portuguese and Canadian authorities (Rocha-Trinidade, 2009; Fernandes, 2010). Increasingly larger groups of Portuguese followed until a peak of 16,300 new Portuguese immigrants were counted entering Canada in 1974 alone (Rocha-Trinidade, 2009). Despite being a relatively new ethnic population at the time of the Jaques murder, the number of Portuguese in Canada was already substantial. By 1980, the Portuguese-Canadian ethnic group was the seventh largest language group in the country—reaching approximately 250,000 in number (Higgs, 1982). The majority of these came from Açores (Nunes, 1986). 
Many of these immigrants moved to Canada in search of opportunities that failed to surface in their homeland after World War II (Higgs, 1982). At the time, Portugal remained largely agricultural and rural, and commerce was still conducted on a small-scale in much of the country, especially in Açores and Madeira (Higgs, 1982; Nunes, 1986). For the Portuguese, this meant that they were not being afforded opportunities others in the developed world found as they sought a more urban lifestyle within more complex markets.

One telling example of this is in the Portuguese engagements with formal education postWorld War II. Anderson and Higgs (1976) found that the majority of adult Portuguese immigrants in Canada at the time of their study had received just four years of formal education in their homeland. This can be partially attributed to the fact that in Portugal both girls and boys were expected to adopt adult responsibilities earlier than was common in Canada, leaving little to no time for formal schooling after a particular age (Anderson \& Higgs, 1976; Giles, 2002). Many early immigrants in Ferguson's (1965) study that came to Canada from Açores explained that education beyond grade four level was simply not available when they were of school-age. Where post-elementary schools did exist, fees proved prohibitive for many rural families (Giles, 2002).

This low-level of educational achievement persisted for many years in the Portuguese community in Canada. In Toronto specifically, over 51 per cent of Portuguese between the ages of twenty-four and sixty-four in 1996 reported having only primary schooling or none at all, and nearly 70 per cent had not finished high school—compared to 31 per cent of all Toronto residents (Ornstein, 2000). This had a significant impact in the lives of the Portuguese in Toronto. The Portuguese were three and a half times more likely than other Toronto residents to report not being able to carry out a conversation in English or French (Ornstein, 2000). It is 
beyond the scope of this examination to explore why educational-achievement remained low in the Portuguese community for many years after they settled in Toronto. However, we may confidently speculate that any negative attitudes surrounding homosexuality carried over to Canada from a relatively conservative and religious way of life remained largely unchallenged as the Portuguese struggled to integrate into their new surroundings and communicate with their new neighbours. This is not to frame Toronto's Portuguese community at this time as less-than other ethnic groups, or suggest that low formal educational achievement results in an inability to critically engage with new ideas. It is, however, necessary to recognize the material obstacles that the Portuguese met in the city at this time in even accessing those ideas that may lead to more favourable and accepting attitudes towards homosexuality.

One important way that the Portuguese dealt with these obstacles was by turning to the family. Nunes (1986) has argued that "the family is the most important social institution in Portuguese life" (p. 14). Indeed Portuguese immigration to Canada itself was fueled by family links, with the nomination and sponsorship features of Canadian immigration policy during the height of Portuguese immigration implicitly encouraging the growth of large family groupings (Anderson \& Higgs, 1976). Very few applicants to the Canadian immigration services listed no prior contacts within Canada during this time (Higgs, 1982). The Portuguese sought unity, mutual aid, support, and regular interaction from their family members, often settling in particular areas in Canada in order to remain close to them (Nunes, 1986). This dynamic extended outwards into other facets of early Portuguese life in Canada as well. Many Portuguese worked for other Portuguese folk, shopped at Portuguese stores, and socialized within Portuguese associations and informal meeting places like bars or restaurants. Effectively, contact between the Portuguese and the wider community was minimal (Anderson \& Higgs, 1976). In 
practice, this created inward-facing communities where little could go unnoticed and nearly everyone was familiar. Anderson and Higgs (1976) have argued that this provided fertile ground for a "telephone gossip network" to sprout where gossip could quickly and easily spread, making it seem like life was lived in a "goldfish bowl" (p. 131-132). It is easy to imagine how this dynamic could have made it extremely difficult to realize and express sexualities that varied from the norm. This becomes even more trying when recognizing that in the traditional Portuguese immigrant family, there is a noticeable effort to maintain the conservative values and customs acquired in Portugal and push away any ideas of change (Nunes, 1986).

This effort is best illustrated in the existing literature in an exploration of gender roles and relations within Portuguese immigrant households (Giles, 2002). In heterosexual firstgeneration Portuguese immigrant households, Giles found that gender relations were often informed by traditional ideologies and remembered dynamics of households in Portugal. This meant that the man was often regarded as the primary breadwinner and leader of the household while the woman was expected to do much of the work in raising the children and maintaining the family home. Alex puts this into clearer terms for us:

My father worked and brought home the bacon, and my momma cooked the bacon and made sure it was sizzling hot right off the pan as soon as he is walking in the door. No matter what happened the night before, no matter how bad the fight was, or whatever happened, he always had a hot meal. A hot meal timed as closely as possible to come out of the oven when he was walking through the door.

Even though most Portuguese women found it necessary to work a full- or part-time job to support a more expensive urban lifestyle in Canada, the majority of them were still expected to do most, if not all, of the household chores (Nunes,1986).

While these examinations are enlightening and help build a useful foundation for understanding the environment that Portuguese gay folk faced in Toronto in the 1970s and 1980s, how these individuals actually responded to them remains almost entirely unexplored in 
explicit terms in these texts. Any discussion of homophobia in the Portuguese community, or of Portuguese-Canadian LGBTQ people themselves, is missing in the foundational texts examined here. When it does appear it is not named, and even then, it is fleeting: Giles (2002) explained, "Needless to say, the only acceptable route out of [Portuguese immigrant] households is via heterosexual marriage" (p. 40). Giles has made the mistake of assuming that the reader already understands why this is true and thus fails to question why it is so.

It is only more recently that the existence of this group has been seriously acknowledged and considered in scholarly literature. Kenedy (2009) examines the collective identity of members of Arco-Iris, a group of LGBTQ Luso-Canadians (Portuguese-speaking individuals) that existed through the late-1990s to the mid-2000s in Toronto. Two participants in Pereira's (2014) study on the educational choices and attitudes of young Portuguese men in Toronto identify as gay, and highlight some of the difficulties they have faced in the Portuguese community. While this work is crucial in the study of Portuguese LGBTQ experiences in Toronto, this particular examination will reach back further to begin to understand the environments that Portuguese gay men faced in the 1970s and 1980s.

While Toronto's Portuguese community was finding its footing in the '70s, the city's homosexual population was also becoming organized and more visible. By the late 1970s, more than 30 organizations and establishments served the gay and lesbian community in Toronto (Nash, 2003). However, the path to acceptance remained overgrown and resistant.

Some may point to Pierre Trudeau's amendment to the Criminal Code decriminalizing same-sex activity between consenting adults in private in 1969 as the moment gay liberation succeeded in Canada. Queer activist, founding member of AIDS ACTION NOW!, and member 
of The Body Politic collective, Tim McCaskell (2016) has recalled the years following the amendment very differently:

We were...still considered an outlaw caste, despised and feared. Not to mention vulnerable. For many young, straight men, queerbashing was a community service. If anyone was actually charged, he only had to say "he made a pass at me" to get off. That seldom needed to happen, though. No gay man in his right mind went to the police in such situations. They were not our friends. (p. 32-33)

Decriminalization, McCaskell has suggested, is not equivalent to legalization. With the amendment came several limitations and few real protections. If someone happened to witness a homosexual act between two consenting adults, for example, it was no longer considered private, and was thus illegal. If either party involved was under 21, regardless of consent and privacy, it was illegal. In the eyes of the law, homosexuality was only tolerated behind closed doors, in silence, and tucked away from Canadians - especially minors. It remained perfectly legal for an employer to dismiss an employee, for a landlord to evict a tenant, or for a bartender to refuse a customer service because they appeared gay. McCaskell has summed it up this way, "The law enforced the social contract of the closet. Keep it hidden and we won't come after you" (p. 33).

For much of the ' 70 s, one could not find any legal prohibitions on sexual orientation discrimination anywhere in the country (Smith, 1999). While Quebec introduced legislation at the end of 1977 prohibiting discrimination on the grounds of sexual orientation, followed by Ontario nearly a decade later in 1986, it was not until 1995 when the Supreme Court of Canada held that the Canadian Charter of Rights and Freedoms extended to homosexuals that other provinces began to follow suit.

As community groups, advocates, and allies grew in number in the interim, so did the challenges they faced. "In many cases, gay organizations were struggling to deal with one particularly difficult situation when they were immediately faced with several more" (Nash, 2003; p. 275). Kinsman (1996) has found this pushback, often from moral conservatives, to be a 
response to what was perceived to be excessively "liberal" or "permissive" reform legislation implemented during the 1960s, as well as new gains won by Black and feminist movements.

Prior to the Jaques murder, Toronto's gay community was already publicly entangled in the homophobic belief that homosexuals pose a threat to children. A 1972 article published by Gerald Hannon of The Body Politic (TBP) entitled "Of Men and Little Boys" argued that children are sexual beings facing forced celibacy under the rule of the nuclear family, drawing the ire of Toronto's mainstream media. Globe and Mail columnist Kenneth Banell linked TBP to the CHAT through its federal Local Initiative Project grants and demanded that its funding be cancelled while the Star publicly wondered if the Criminal Code amendments decriminalizing homosexuality should be revoked, and the Toronto Sun declared, "I told you so" (as cited in McCaskell, 2016). Despite CHAT president George Hislop releasing a statement distancing the group from Hannon's article, the federal grant was not renewed. Hannon responded by penning "Children and Sex" in the next issue, arguing that the reaction from the press merely proved that children were looked upon as property. The mainstream media did not back down either- the Star's publisher pointed to Hannon's article as justification for a ban on TBP ads in his paper, and used their eighty percent stake in the printing company in charge of the TBP file to stop the presses on the magazine completely (McCaskell, 2016).

South of the border Christian Evangelical, former Miss America, and famed orange juice promoter Anita Bryant successfully led the first formal campaign against the gay movement's political agenda by winning the repeal of anti-discrimination protection for gay people in Dade County, Florida (Nash, 2003). Bryant's "Save the Children" campaign was widely reported on in Toronto, including her claims that when permitted, "Homosexuals [would] recruit our children" and "they [would] use money, drugs, alcohol...any means to get what they want" (as cited in 
Nash, 2003, p. 280). Sensing the possibility of Bryant's anti-gay sentiment stretching north, the Ad Hoc Coalition to Stop Anita Bryant formed in Toronto in June 1977. McCaskell (2016) recalled a march that saw Coalition members flowing in and out of bars chanting, "Out of the bars, into the streets, gay liberation now!" and a rally of 700 at city hall (p. 81-82).

That same month the Ontario Human Rights Commission (OHRC) published Life Together, a report that called for an amendment to the Human Rights Code that would see sexual orientation protections included. Nash (2003) has found that while the mainstream media in Toronto generally responded favourably albeit with some trepidation, save for the Sun who were outright opposed and appalled, concerns about homosexual contact with children were also published. The belief that homosexuals seek children for their own sexual pleasure, or even to convert to homosexuality, remained persistent.

When news broke that four men were charged with kidnapping, raping, and murdering Emanuel Jaques shortly thereafter, "The terrain of gay politics...fundamentally shifted" (McCaskell, 2016, p. 73). LGBTQ2+ community members distanced themselves from the murderers, and called for an end to homophobic press coverage. "But it was like shouting in a hurricane," McCaskell (2016) recalled (p. 74).

In late December of 1977 it was announced that Anita Bryant was kicking off a crossCanada "Christian Liberation Crusade" with a rally at the People's Church in North York in early 1978. Astonishingly, North York mayor Mel Lastman announced plans to award her a medal for "her crusade against homosexual activists" (as cited in McCaskell, 2016, p. 82). Ross (1990) has concluded that Bryant "succeeded in monopolizing mainstream media and stirring up an already vicious homophobic fundamentalism in new-right forces” (p. 78). 
On December 30, 1977, police raided the offices of TBP. After over three hours combing through material while McCaskell stood by, they ultimately left with administrative records, manuscripts, archival material, classified ads, unopened mail "and worst of all, the subscription lists" with the names of thousands of readers (p. 78). At the center of the raid was supposedly a contentious new article by Hannon entitled "Men Loving Boys Loving Men" including interviews with three men about their relationships with boys as young as twelve—published just months after the Jaques murder. $T B P$ faced two charges: one relating to the publishing of Hannon's article and the other for possessing material for purposes of distribution for their supply of a book already cleared by Canada customs.

For McCaskell, "There seemed less and less hope for the amendment" to the Human Rights Code (p. 84). Dorothea Crittenden, the chair of the Ontario Human Rights Commission at the time, blocked any progress in this fight. She explained to the Sun that because of the Jaques murder, it was not the right time to deal with the sexual orientation issue (as cited in McCaskell, 2016). Ultimately, she never did.

Less than a year after $T B P$ raid, the Toronto police carried out the first of a number of raids on gay bathhouses in a three-year period. Twenty-six men were arrested at The Barracks, and several were injured (Nash, 2014). The following morning, George Hislop, a 10 percent shareholder in the bathhouse, was also arrested. Kinsman (1996) has argued that this police offensive was "an attempt to regulate the gay-male community, and our sexualities" (p. 341).

"It really did seem that we were under attack," McCaskell agreed (p. 97). Ross found that "for the first time, hate literature targeting lesbians (as distinct from gays) was strewn over Toronto streets" (p. 78). 
It was over this background that the individuals included in this research were to come to understand their own sexualities as something to be hidden, suppressed, and even feared.

\section{On the Murder}

The Emanuel Jaques murder has captured the attention of writers, journalists, filmmakers, playwrights, musicians, and scholars for over 40 years. Portuguese-Canadian novelist Anthony de Sa (2013) has set a fictional coming-of-age story in Toronto's Portuguese community around the murder. Bill Moniz's (2006) hour-long documentary on the events of ' 77 was broadcast by Canadian multicultural television channel OMNI. More recently, true crime writer Robert Hoshowsky (2017) has revisited the details of the criminal case, and a number of Canada's most prominent newspapers marked the 40th anniversary of the murder in 2017 with new articles and columns. For our purposes, however, a review of the scholarly research completed on the Jaques incident proves most illuminating.

First to analyze the murder and the response that followed in-depth was Yvonne Ng (1981). Ng has focused on the "clean-up" campaign surrounding Yonge Street that was accelerated by the moral panic that followed the Jaques murder. They have argued that although the clean-up campaign had begun years earlier, "The tragedy was turned into a 'trigger' by the politicians to neutralize dissent" (p. 1). Much of their work considers the news media's role in this campaign as an often uncritical messenger between the State and the public, engineering popular consent by disseminating and reinforcing conservative ideas about sex and sexuality. The media takes up this position, Ng has argued, not by some conspiracy but because of journalists' reliance on so-called "accredited sources" in response to the structural constraints they face, and in maintaining the appearance of objectivity and neutrality. The voices of authoritative sources representing the State, like politicians, police officers and judges, were thus 
able to steer the media and its readers without much challenge towards particular stories, packaged with parallel ways to understand them, in their role as the "primary news definers" ( $p$. 23). The Jaques case could be mobilized by politicians seeking to advance their own agendas, Newman (2002) has suggested, because it "operated on the level of myth, drawing on old, but still valent fear-mongering discourses about contagion, instability, and danger" including "tales of homosexuals as child molesters and murderers" (p. 149). In other words, the Jaques case resonated so deeply with so many people because of its myth-like quality that activated alreadyexisting fears about homosexuals.

Newman (2002) has continued along this vein, focusing the bulk of their work on developing a deep understanding of the spatial contestation processes at work on Yonge Street during this period. They have argued that one of the functions of spatial contestation is to establish the normative, respectable citizen. Although the amendments to Canada's Criminal Code in 1969 made it harder to prosecute homosexual acts done in private, it "had the effect of delineating public space as the arena for legal regulation of morality and sexual behaviour" ( $\mathrm{p}$. 137). As a result, sexual minorities were made especially vulnerable in the contestation of public space. The actions carried out by politicians and law enforcement on Yonge Street in the months following the Jaques murder are a clear illustration of this process of regulation in action. Statements given to the media by prominent politicians including Ontario premier Bill Davis, Toronto Mayor David Crombie, and several Aldermen make this even clearer, as they have been found by Ng to show that it was not the murder of Jaques but the "clean-up" of Yonge Street that concerned them most. With that said, there are several other subtler and insidious ways that a normative and respectable citizen was being constructed in the daily lives of homosexual people 
that is not considered in Newman's work. Their implications ultimately go unrecognized, but are explored in this thesis as they relate to Portuguese gay people during this time.

Ng's suggestion that the media itself was guilty of fueling the vilification of homosexuals - intentionally or not - is particularly useful in this regard. This included the highlighting of the rape of Jaques in headlines and stories in all of Toronto's dailies (sometimes in graphic detail), the juxtaposition of a story on a press conference held by gay community leaders against a special feature on gay prostitution in The Globe and Mail, as well as overt opposition to gay rights and homosexuality in the Toronto Sun. In stories published after the Jaques trial concluded, $\mathrm{Ng}$ found the sexual preferences and histories of the three convicted murderers retold in great detail. "The relationship between homosexual behaviour, pedophilia, and murderous acts became a cluster of images that cemented in the public mind," they concluded (p. 57). Defined in such a way, the Jaques murder became a common refrain used in the "threat-to-children" argument that proliferated in opposition to the pursuit of human rights protections for homosexuals (Nash, 2003; Kinsman 1996).

Newman (2002) has taken these studies further by investigating the Jaques murder through the lenses of race and class. They propose that in the "clean-up" campaign, homosexual bodies were put through a process of racialization, marked as different from the norm, as degenerate, and as a threat to whiteness in opposition to the white politicians who were constructed to be the "saviours of respectability" (p. ii). This framework proves especially helpful in Newman's exploration of how the Jaques murder precipitated a complex process of spatial control meant to reaffirm whiteness, heterosexuality and middle-class status as the norm. However, it is limited in this particular application as the ability of participants to "pass" as heterosexual becomes more salient and this process of racialization in the "clean-up" campaign 
was unable to find its intended mark among them. Since no participants here were openly living as gay at this time, the conflict they recall facing following the Jaques murder occurred mostly internally.

Like Newman, Nash (2003) is also interested in spatial concerns surrounding the Jaques murder, occurring just outside of what she terms a "commercial gay ghetto." Nash has suggested that the murder was linked to the homosexual population in mainstream discourse because it occurred just a few blocks away from the CHAT community center and what was then considered an area heavily populated by gay people. In turn, homosexual spaces were reconstituted as potentially dangerous in the panic that followed, especially if they were visible. Similarly, Kinsman (1996) has suggested that the "clean-up" campaign and the discourse surrounding it spurred the growth of feelings against the visibility of the gay ghetto in the Yonge Street area. To illustrate this point Nash found that the progressive conservative candidate for North York at this time, John Gamble, stated to reporters that CHAT "publicly displays the purpose of its existence," and that "had it not done so...the accused might never have located where they did and might never have met the Jaques boy" (p. 287-288). In the same article Gamble went on to suggest that the killers lived in the "gay area" because it offered convenient access to children on city streets.

Brock (2009) has approached this incident from the perspective of the sex workers who worked on Yonge Street during this time and were also identified as folk devils in the panic. Between mid-July and 2 September 1977, 224 charges were filed against "inmates" and "keepers" of common bawdy-houses. This in comparison to only 16 similar charges laid from June to July 1977. "Women were literally rounded up and loaded into paddy wagons by police," they note (p. 38). By December 1978, the last body rub parlour on Yonge Street had closed, 
despite city officials predicting it would take five-years to complete the clean-up campaign when the Report of the Special Committee on Places of Amusement was released in June of 1977 (as cited in Brock, 2009). The connection here is clear, and it is difficult to imagine that such a quick and conclusive police action could have been completed without the Jaques murder precipitating it. Brock has concluded, "Whatever resistance there had been to a clean-up was silenced" after the Jaques murder as action against gay men and sex workers was made to seem legitimate and warranted by the panic (p. 35).

Newman (2016) returns to this work more recently to introduce deeper considerations of surveillance and regulation into the discussion. They have argued that by positioning gay men and sex workers as a threat, in opposition to the martyr-like image of Jaques, this incident was used to justify the heightened surveillance of gay men and sex workers on Yonge and subsequent efforts to regulate and displace them. They are also correct in pointing out that by this time in the city, the Yonge Street strip was undergoing a massive transformation with the opening of the Eaton Centre in February 1977, designating "land on and around Yonge Street...prime real estate" (Newman, 2016, p. 222). The adult businesses on Yonge thus stood in the way of the powerful economic interests converging on the strip, a fact that Toronto's politicians were no doubt aware of. This thesis takes this further by showing how the murder and the narratives it spawned encouraged Portuguese gay men to take this project on to themselves to survey and regulate their own sexual expressions. 


\section{Methodology}

This work draws on five semi-structured interviews with Portuguese homosexual men who lived in Toronto in the 1970s and 1980s and continue to reside in the city. Each interview was based on the same interview guide (see Appendix A), and the ensuing conversations ranged from 45-minutes to three hours. The ability of semi-structured interviews to "provide detail, depth, and an insider's perspective" in ways that other interview styles may not made them best for a study that seeks to uncover an inside-look at a previously unresearched population (Leech, 2002, p. 665). Semi-structured interviews are designed to keep interviews moving in a certain direction but allow researchers and participants flexibility by using mostly open-ended questions and an interview guide rather than a strict set of questions. The interview guide used for these interviews was crafted to encourage participants to touch on each frame of CTI during our discussion (Jung \& Hecht, 2004).

Three of the five interview participants were recruited using purposeful sampling techniques, initially by contacting researchers and support workers already active in the Portuguese community, and then connecting with individuals through email addresses provided during this first step. At the same time, a small number of LGBTQ Portuguese people named in articles published in the queer magazine Xtra were contacted through publicly available email addresses and social media profiles. Digital recruitment posters were also shared through Twitter and in queer groups on Facebook, but these did not prove fruitful.

Two participants were recruited using snowball sampling. This required asking alreadyrecruited participants if they could identify any other individuals who may be interested in contributing their voices to this work. Woodley and Lockard (2016) have maintained that snowball sampling is a non-obtrusive sampling technique that allows researchers to access 
marginalized populations that are not easily accessible_-like the population that I have accessed here. In the process participants would often suggest one another, leading me to believe that the population I was trying to navigate was indeed as small as I had initially anticipated. This is not necessarily because there are very few LGBTQ Portuguese folk who lived in Toronto during this period, but may be because it can still be difficult to be visible as a LGBTQ person in the city's Portuguese community. While some convincingly argue that snowball sampling may result in biased data by leading researchers through already-existing social networks with a limited scope of views and perspectives, this is not reason enough to dismiss this research. Sydor (2013) puts it simply: "Biased information is better than none" (p. 36). Since this research seeks to introduce new perspectives into this history rather than uncover a representative Portuguese LGBTQ experience of the Jaques murder, snowball sampling proved to be a useful technique in accessing as much of this population as possible in the absence of any organized Portuguese LGBTQ community groups available to address.

Initially I set out to recruit Portuguese individuals from all points of the LGBTQ spectrum with a kind of quota sampling methodology. Only one trans-identified person could be identified, but my introductory email was not responded to. Two women initially expressed interest in participating, but I was unable to reconnect with them after sharing additional information about the study. It is true that there is also less published material identifying lesbian, bisexual, trans, or queer Portuguese women whom I could contact. I can only speculate as to why it proved significantly more difficult to recruit women for this study. It is possible that being a cisgender man played a part, and that a woman or trans individual may have more success accessing these populations. There are also different pressures that Portuguese trans individuals and Portuguese queer women face that queer men do not, each contributing to the 
current lack of visibility for these populations. What is clear is that this area of study could significantly benefit from the inclusion of these individuals, and that this work need not and should not, be the last of its kind.

While the thrust of this work focuses on the Jaques murder and the moral panic that followed, the interviews themselves had a larger scope. By beginning the interview with what it is like to be both Portuguese and gay in Toronto today, participants were able to provide a frame of reference that they could use when recalling events that occurred decades ago. It also allowed them to enter into the conversation more easily without having to rely solely on memory. Next, I encouraged participants to speak about their childhood and the experience of growing up in the Portuguese community in Toronto, allowing them to lay a foundation of contextual information to build on. This also offered a considerable amount of time to build the rapport and comfort required before speaking about the Jaques murder, and their sexualities more specifically.

Throughout, participants were given the space to guide the conversation. I was careful to limit my own participation to gently encouraging participants to say more where possible, asking for clarification where needed, and offering new questions from the interview guide when participants had finished a thought. In some cases, participants provided sufficient responses to questions that had not yet been asked so I simply skipped those questions when we arrived at them or asked if there was anything else they would like to add. It is crucial, in my view, to provide individuals in marginalized communities the opportunity to speak about what is most important to them when given access to the scholarly circles we as researchers represent. This is especially true for the Portuguese LGBTQ community in Toronto, where very little scholarly attention has been directed to date. All participants were also given the opportunity to add anything they thought we did not adequately discuss at the end of each interview. While my 
primary goal was to discover how Portuguese LGBTQ people in the city experienced the Jaques murder and the panic that followed, a fact that participants were aware of from the beginning of the recruitment process, I would be doing a great disservice to the participants of this study and others in Portuguese and LGBTQ2+ communities if I failed to recognize the importance of the additional information participants shared about what it means to be Portuguese and gay more generally in Toronto. That information will make up a significant portion of the discussion that follows, not merely as an addendum, but as a crucial part of the story of how Portuguese gay men responded to a culture where a moral panic of this kind could take hold.

It is important to note that, for the most part, interviews were conducted solely in English. This is due to the fact that I cannot speak Portuguese at a level where this kind of communication would be comfortable or efficient. It is likely that a researcher who is fluent in Portuguese may be able to invite other voices into the conversation that I cannot currently accommodate. All participants included in this research were comfortable conducting the interview in English and can fluently speak in the language.

Multiple steps were taken to respect participants' and potential participants' right to privacy throughout the research process. Password-protected communication channels preferred by participants (like email or Facebook messenger) were exclusively used to share study information that could reveal a participants' inclusion in the study, unless a participant explicitly indicated that phone calls or text messages were preferable. Facebook messenger was used through my personal profile to communicate with one participant, and to reach out to other potential participants whose profiles were shared via snowball sampling. In each case, participants and potential participants were made aware that becoming Facebook "Friends" was not necessary, and may actually reveal their participation or interest in this study. These 
connections were only made if participants remained intent on becoming "Friends" after such a risk was outlined. While this dynamic may be a relatively new one in qualitative research that requires extra care and thought (Fileborn, 2016), it did not change the data collected (no information published on a participants' Facebook page is used in this study) and merely facilitated private communication. Facebook also proved to be particularly helpful in contacting people in this small population whose email addresses were not known or publicly available. No follow-up emails or messages were sent to potential participants unless they had expressed interest in participating after our first contact.

These channels were chosen as the preferred form of contact to minimize any risk that my communication with participants and potential participants could make their sexuality or gender identity known to those who may otherwise be unaware, making them vulnerable to unwanted and unintended consequences. This risk was further minimized by carefully crafting initial recruitment emails not to assume the sexuality or gender identity of the individual I was contacting, but to ask if they might know any Portuguese LGBTQ folk who are interested in participating in such a study. This allowed participants to volunteer themselves if they were indeed part of this group and felt comfortable doing so, suggest other people who fit the criteria, or ignore the message altogether without consequence.

Informed consent to participate in this research and have responses audio recorded was obtained from participants prior to the start of each interview in-writing. All participants were also provided an electronic copy of the Consent Agreement with information about the study, counseling resources, and their rights and responsibilities as participants at least a week before the interview was scheduled to take place. This came with the assurance that they could direct any questions they may have about the study to my research supervisor, the Ryerson University 
Research Ethics Board, or myself. In one instance, I met with a participant prior to scheduling the interview itself to help them through the Consent Agreement and provide the information in it aurally. Each participant was reminded at the start of the interview that they could skip any question at any time, or withdraw from the study for whatever reason. No one chose to do so.

Additionally, all participants were given the option to review transcriptions produced from their responses to delete, change, or add information provided during the interview. Each elected to do so. This ensured that all participants could be confident that they would not be misrepresented in this research, and allowed them to reflect on and add any relevant information that may not have been given during the interview itself. In one case, I held a follow-up meeting with a participant who was struggling with the transcription on their own to go through it with them and record a few short explanations that they thought necessary to add. These were then transcribed and inserted into the original transcription.

All participants were informed that interviews would be made confidential by default prior to the interview, and that their identities would only be known by my research supervisor and I. However, I did provide the option for participants to consent to using their real-names in the study, recognizing that some individuals would like to speak publicly about their experiences, and three elected to do so. The names of the others have been replaced with pseudonyms, and all identifying information that may point to them was removed from the data at the time of transcription. All interviews were conducted in a space with aural and visual privacy chosen by the participant where they could feel comfortable. Four out of five interviews took place in private at Ryerson University, and the fifth occurred at the participant's apartment. Audio recordings obtained during said interviews were permanently deleted from passwordprotected computers after transcriptions were completed so that responses given by participants 
who chose to remain anonymous could not be traced back to them in the unlikely event that the audio recordings were obtained by other parties. Transcriptions were stored digitally on the same computers and shared directly with participants for review via email. Only one transcription was printed to be given to a participant who requested their typed-up responses in a physical form.

CTI was drawn on again during the analysis of this data. Working with Kuckartz's (2013) illustration of thematic qualitative text analysis, the four frames of identity constituted the main thematic categories the data was first coded within. Qualitative research software (NVivo 11) was used at this point of the research process to easily code interview data. A thorough reading of each transcription was conducted and passages were separated into either Personal, Enacted, Relational, or Communal based on which frame(s) of identity were most clearly present in each passage. This resulted in a significant amount of overlap, and did not go far enough to break the data down into manageable pieces.

A second coding process was needed to differentiate the data collected in each main category into more useful parts, so a number of subcategories were created. These subcategories are outlined in the table below (See Appendix B for operational definitions of each subcategory):

\begin{tabular}{|l|l|}
\hline $\begin{array}{l}\text { Main Categories } \\
\text { (First Coding) }\end{array}$ & $\begin{array}{l}\text { Subcategories } \\
\text { (Second Coding) }\end{array}$ \\
\hline Personal & Self-Images \& Concepts, Beliefs \& Convictions \\
\hline Enacted & $\begin{array}{l}\text { Learning, Community Engagement, Cultivating, Expressing Sexuality, } \\
\text { Expressing Gender }\end{array}$ \\
\hline Relational & $\begin{array}{l}\text { Attitudes Surrounding Homosexuality, Family, Friends \& Partners, } \\
\text { Gender Roles \& Relations, Trauma }\end{array}$ \\
\hline Communal & Portuguese Community, LGBTQ2+ Community, Religion \& the Church \\
\hline
\end{tabular}


These subcategories refer to a number of recurring themes and topics that emerged in the data under each frame of identity. All transcriptions were read-through again and all data was recoded using this more elaborate category system. Naturally, some overlap did remain, but that overlap could now be more easily understood. Text passages that did not apply to any subcategory were left out of the dataset at this point.

With interview data thoroughly categorized into usable parts, analysis was now possible. A participant's thoughts on any theme identified in this process could be easily retrieved, compared, and contrasted with what other participants may have said about the same topic. This system also made it easier to identify how and why participants felt compelled to negotiate their identities in a particular way. For example, a participant may have felt unable to authentically engage with the Portuguese community because their self-images ran counter to how they felt they were able to express themselves in Portuguese spaces. To make analysis simpler, an additional category was created to more easily retrieve memories about and reflections on the Jaques murder specifically.

Overarching themes and stories that emerged across the data guide the rest of this work. These include: community and family life, and experiences of invisibility; fear, confusion, and guilt about the Jaques murder, as well as critiques of the responses it inspired; connection and disconnection, engagement with Portuguese and LGBTQ2+ communities, and new ways of being both Portuguese and homosexual. 


\section{A State of Invisibility}

Growing up gay in Toronto's Portuguese community through the 1970 s and '80s, often meant living in a state of invisibility for participants in this work —a state that was both inherited and continually reinforced. When prompted, no one interviewed here could remember any openly gay individuals in the Portuguese community in the ' 70 s and ' 80 s beyond mere suspicions and "gaydar" blips. The absence of openly gay folk already living in the community suggests that an environment where homosexualities could not openly express themselves was already well-established by the time these men were coming to understand their own identities. In this chapter I will examine how these men experienced their sexualities growing up in the Portuguese community, within their families, and in the city more generally to develop a deeper understanding of what it was like to be gay and Portuguese in Toronto at this time.

\section{The Community}

By virtue of their ethnic roots, participants were in some way connected to and affected by the Portuguese community in Toronto. The ways participants characterize the community at this time differ depending on whether or not they lived in a predominantly Portuguese neighbourhood, or were heavily involved in the community or not. Alex, who grew up near Dufferin and Dundas, gives us a useful picture of what one of these neighbourhoods was like:

We had one non-Portuguese neighbour, a white guy, across the street and it was one door up. Everybody else was Portuguese. Everybody else was Portuguese. A lot of people from the same village came over within a short period of time from each other so it's almost like villages, entire villages, were transplanted to some neighbourhoods.

Neighbourhoods like this emerged because many Portuguese in Toronto settled in a relatively small circle of the city. Jorge sketches this out for us:

We lived at Bathurst and Queen, where all the Portuguese lived. College, Bathurst, Bellwoods, Crawford, Grace...Dundas and Lansdowne. This is all the Portuguese 
community. And so this Portuguese community lived in this circle. But they never went any further than Spadina. They never went further than Davenport, Lakeshore, High Park.

These descriptions bring to life Anderson and Higgs' (1976) contention that many Portuguese in Toronto at this time could be defined as "urban villagers living in insulated communities" ( $\mathrm{p}$. 131). According to Gans (as cited in Anderson \& Higgs, 1976), an urban villager is an immigrant who hails from a relatively isolated village who now lives in a small community of fellow immigrants within a North American city. It is thus necessary to understand such a community as distinct, with its own values and beliefs that are not easily swayed by movements taking hold in other communities around the city. Alex gives us a sense of what it meant to live in such a community with a sexuality that differed from the norm. He explains:

You know, I would always feel crowded. Everybody knew everybody's business, and no privacy. Maybe I was more conscious of that because of the gay thing, because of being gay. And just so religious, oh my god...Just religion was part of everything everywhere all the time.

Such a characterization also mirrors Anderson and Higgs' (1976) definition of the community as a "goldfish bowl" where little privacy could be found. The specific language Alex uses here is important to recognize. He speaks in absolutes with no room for ambiguity, using evocative words like "always," "crowded," and "everybody." This way of speaking directly points to a specific experience of growing up in fear that a secret like the "gay thing" once uncovered by another in the community may not be contained within the crowd - where everybody participated in observing the fish in the bowl. Implicit in the recognition that he was more conscious of this feeling because of his sexuality is Alex's childhood belief that the consequences of such a revelation would be largely negative in his ethnic community. 
Not all Portuguese lived in one of Toronto's predominantly Portuguese neighbourhoods at this time, including Adriano. He describes the community in quite different terms than those Alex uses:

Like a very close-knit community. I had a lot of family here as well who emigrated from Portugal. I had a big church gathering...Eventually became part of the church youth group, and Sunday school teacher. But I always felt immersed in it because my parents were, we were growing up in it, we saw our family, we saw our friends in the church community. So very involved there.

While both Adriano and Alex offer similar descriptions of the community as one that is strongly pulled together by ethnic, religious, and familial bonds, the connotations of each are markedly different. A "very close-knit" community is one where members rely on each other for support, not necessarily "crowd" one another. Adriano's recollections of feeling "immersed" and "involved" in the community differ from Alex's in that his descriptions implicitly point to associations between his membership in such a community that are more positive and less fearful. For the Portuguese community at this time, both of these descriptions are true. Which description proves more salient likely depended on one's perspective and place within it. Living elsewhere gave Adriano more opportunities to get away from the "crowd" and the pressures of living where little privacy was allowed. Trevor, who lived in the suburbs away from other Portuguese in the city, does not speak about a fear of seeing his sexuality disclosed that is linked to his place in the Portuguese community either.

However, this does not mean that these men were immune from popular attitudes surrounding homosexuality in the Portuguese community at this time. In considering why he felt unable to speak about his sexuality while growing up, Adriano explains:

That's how it felt. Who did this? Did anyone say that to me? No. It's just how I felt. I couldn't speak to my mom about it, or my dad, or my family. I just got it from our community, from our religion, that it was a bad thing. 
Implicit in such a statement is Adriano's observation that homosexuality was taboo in the Portuguese community and not to be talked about. Although he was not caught in the "goldfish bowl," negative attitudes surrounding sexuality in the Portuguese community were still very much present through the communal frame of his identity and thus had a significant effect on how he could, or could not, express his sexuality. When explicitly asked what some of those attitudes were, Adriano explains:

Oh, it was evil. It was a sin. You did not want to be gay or found out to be gay, that's for sure. That's all I remember, was just like a no-no. You know, you hid it. It's not like today where you kind of are proud of it...There wasn't anything to be proud of.

The environment Adriano observed was extremely hostile to homosexuality at this timeinformed in part by religious views that labelled it with its own language as an "evil" or a "sin." When homosexuality was talked about or represented in another way, Alex explains, "It was a joke."

Looking back now, Gilberto observes that homosexuality was certainly present in the Portuguese community, but entirely hidden or denied. He explains:

Where, you know, men have a certain attraction toward other men but because of the taboos and the culture, religious and so forth, they just kind of hide it, or pretend it doesn't exist, or don't let on, but they're still doing stuff in the shadows beyond their family life... There's a bit of a, 'Don't talk about it,' attitude...You know, burying your head in the sand, sort of attitude.

No men identified any positive attitudes surrounding homosexuality in the Portuguese community at this time while defining those attitudes that they observed in their youth. It is possible that these attitudes did exist, but the fact that none are recalled suggests that they were overshadowed by negative ones.

Like Alex, Gilberto grew up in a predominantly Portuguese neighbourhood. His experience, however, is significantly different because his family was "never really very connected to the Portuguese community." He explains: 
At the time, my parents, they both came from Portugal with a grade four education and my father was always very gung ho and sort of hardworking. And when they came to Canada they had two jobs. My sister and I were kind of left to fend on our own, pretty much. For a few years anyway. Early on they wanted to buy a house and so they worked a day job and they worked a night job so my sister kind of looked after me, and we lived in a house that had other people living there, other Portuguese people as well.

Gilberto's experience introduces considerations of class into this discussion and points to the fact that not all Portuguese people could spare the time to participate in the community even if they did live within it. This is not to say Alex's experience of feeling "crowded" by the community is exclusive to him, even though it is unique amongst participants included here. It is possible that other gay men who grew up within the community had a similar experience. What this difference makes clear is that participants connected with the Portuguese community in very different ways. While Anderson and Higgs' (1976) descriptions of the Portuguese community at this time do shed some light on what the community looked like, they are seemingly contingent on one's physical placement in relation to other Portuguese in the city and ability to participate within it. It does not tell us enough on its own about how Portuguese gay people in Toronto experienced their sexualities at this time. Their connection to the Portuguese community was mediated by several different factors, including social class, enabling some families to live in large houses in the suburbs away from predominantly Portuguese working-class neighbourhoods, like Trevor's, or limiting them from taking part in many community activities, like Gilberto's. For Trevor, the passing of his parents when he was a teenager also damaged his connection to the Portuguese community. Unlike one's physical placement relative to predominately Portuguese neighbourhoods and involvement in the community, the negative attitudes surrounding homosexuality that participants observed were more difficult to escape as they were not so limited by geography and followed participants more closely as part of the dominant attitudes in the communal frame of their identities. 
It is beyond the scope of this examination to trace the roots of such attitudes. What all participants make clear is that the Church played a role in defining homosexuality in negative terms in their lives. Adriano, who was very involved with the Roman Catholic Church growing up, deeply struggled with particular readings of the bible that define homosexuality as a sin. Trevor, who went to a Catholic high school, remembers that "homosexuality was actively discouraged," and a complete lack of HIV/AIDS awareness or education. Given the central role of the Church in Toronto's Portuguese community at this time, it is quite likely that its stance on homosexuality heavily influenced the beliefs Portuguese people in the city shared. The influence of the Church was no doubt substantial, and will be returned to in discussions of the family, and later when considering how Portuguese gay men came to embrace their sexualities.

\section{The Family}

Common amongst all interviews conducted for this work is a significant reflection on what it meant to be gay in the Portuguese family during this time. Nunes (1986) assertion that the family is held as the most important social institution in Portuguese immigrant life certainly applies in these cases. Negative attitudes surrounding homosexuality that seeped into the family proved to have a significant impact in how participants could enact their sexualities as young people, as well as their relationships with family members after coming out.

Adriano explains that when he was growing up he had never planned to come out to his parents, primarily because of how religious his mother was. When he was 21 , however, the nature of his sexuality was uncovered by his mother without his knowledge.

I used to keep a journal, and I used to write everything that happened. Well not everything that happened, my thoughts. My thoughts on stuff, and how I felt. So it was more of an emotional journal. And sometimes our thoughts are worse than our actions. So our thoughts like, "Oh my god I would love to," you know, "This with that guy. He's so beautiful. I'd love to...," whatever. And my mom found it. She didn't speak English or 
read English so she had my brother translate it. And unfortunately that's what happened. He translated the whole thing. And that's how they found out.

His mother had Adriano go speak to their priest, and the priest explained the situation to him, assuring him that his mother still loved him and accepted him for who he is because, as Adriano remembers, “That is who Jesus gave to her." Having known his mother's thoughts about homosexuality, Adriano was shocked by this response. Unfortunately, the situation he found at home was very different.

A lot of physical abuse. Having my mom say to my dad, "He's not listening to me." You know, "Slap some sense into him." And my dad of course hitting me but not, I found out later, not knowing why. He's just doing it because my mom is telling him to...It was, "I'm the devil. "We're going to get it out of you,"' that kind of thing. So that's how the abuse started. And I just got tired of being hit. So I left.

Throughout his time away, his mother was calling him at work begging him to come home.

And I said, 'No, no. I'm not going to come home because you're hitting me, you're yelling at me. There's nothing wrong with me. You say I'm full of the devil-I'm not.'

After five to six months, Adriano returned home on the condition that the abuse would stop, and in large part to reconnect with his younger sister who his mother forbade him from seeing until he moved back in. Shortly thereafter, it became clear that his mother's thinking had not significantly changed and the abusive behaviour started again.

She took me to the bathroom, opens up the cupboards and says, "This is woman's perfume, this is men's cologne, you use the men's not the women's." And I just lost it. I've never sworn to my mother. I yelled at her. I said, "Get the fuck away from me you stupid fucking bitch." And she's like, "Ah, Adriano, Adri-" And I'm like, "Get the fuck away from me." And she went to hit me, and the couch was behind her and I just pushed her down. And I said, "You lay one hand on me and that's it, I'm out of here for good." That did it. She stopped.

It is clear that Adriano's fear of coming out to his parents was not unfounded. The abuse he suffered represents a significant effort to banish homosexuality from within the family unit based on the false belief that it is an "evil" that can be denied or forcibly eliminated. The episode in the bathroom illustrates the fact that, for his mother, his sexuality also threatened normative notions 
of masculinity that she valued and thus required additional correcting. Sexuality effectively becomes entangled with gender roles and expressions here, and any imagined breach of normative gender roles is explicitly discouraged as well. Adriano's experience is a significant example of how beliefs that portray homosexuality as an evil that can be corrected manifest in harmful ways in a Portuguese household.

Notably, such an experience did not only affect Adriano. Alex, who was in a youth group at the community church with Adriano and several other Portuguese youth who turned out to be gay, saw Adriano's experience as a cautionary tale. He and others in the group believed that hiding their sexualities from their own families was necessary because of what such a disclosure meant for Adriano.

The fact that none of us came out to our families tells you how it would have been received. It wasn't imagined...I was not gonna take that chance. Especially after I saw what happened to him. My god, there was no way in hell.

...It's a safety thing. If you're 18-years-old-Man, when I was 18-years-old I wasn't going to come out to my parents first and everybody all at the same time. Boom, boom, boom. I'd be out on the streets so fast.

For young gay people growing up in the community around him, Adriano's experience exemplified the risk of being outed as one that carried significant consequences, like violence, rejection, or expulsion. To those who noted such a risk, it understandably seemed necessary to hide their sexuality away from their family until they deemed it was safe to disclose that part of their identity. This meant, in large part, ensuring that the identity enacted in and around the family could confidently pass as heterosexual.

On the other hand, Jorge had family members seemingly take it upon themselves to attempt to hide his sexuality when he was growing up. As a young teenager, Jorge was arrested while cruising at a subway station bathroom. When he was brought before a judge accompanied 
by his mother, who could not speak English, and his brother, who could, his brother refused to translate the proceedings for his mother.

When I got home my brother told my dad that I had been arrested for stealing. Why didn't my brother tell the truth? Maybe at that time I would have gotten help.

We cannot fully understand why Jorge's brother chose to hide the nature of his arrest, but the violent homophobia Jorge recalls facing from his family later in life suggests that such an effort was an attempt to make his sexuality invisible at the first signs of its appearance. It is important to note that Jorge did not correct such a lie either, likely realizing that it was safer to be considered a thief than a homosexual in his household, where homosexuality was considered taboo. He explains:

We never got to explore our sexuality because our Portuguese parents didn't want to talk about it.

Ultimately, he was encouraged into silence by both a rejection of his sexuality when it appeared, and the knowledge that his sexuality was not a topic his parents were willing to discuss.

An environment where homosexualities were denigrated and discouraged within the family manifest in more covert ways as well—often by the way homosexuality was invoked in language. Jorge remembers being mocked as a child by his family for only playing with girls, and being called "sissy" and "maricinhas" (a Portuguese slur for "homosexual"). Gilberto picked up on similar language around him even though it was not directed his way. He explains:

You might say to someone, 'Oh, that asshole,' or 'That idiot,' whatever it is. My parents would say, 'Ai, aquele paneleiro.'

"Paneleiro," meaning "gay" or "faggot" depending on the context it is used in, emerged for Gilberto as a slur synonymous with "asshole" and "idiot." Trevor had a similar experience with a cousin who he looked up to as a child. 
She used the word "faggot" so many times. Not at me. But it—if we were driving down, 'Oh look at those two. They look like faggots.' I was 10, 11, 12-years-old. I didn't know what to say. I didn't even know I understood, I just realized she thinks they're bad people. From a young age, Trevor was being taught that homosexuals were "bad people" in the ways homosexuality was spoken about around him. These lessons were not didactically and directly delivered, but gleaned from everyday conversation. "Homosexuality" as a category was effectively deemed an unfavourable space in the ways its classifiers were used around participants. It was thus necessary to avoid being stuck with such a classification. According to Pharr (1997), the fear of being called "sissy," "faggot," or one of the several other pejorative terms often strewn at effeminate boys, pushes many to constantly survey their behavior in an effort to align themselves with approved societal gender roles that they observe around them. Indeed, Gilberto felt compelled to alter the ways he acted and spoke around certain people to avoid said classifications.

I never saw myself as being this sort of "macho, butch" kind of a guy. But definitely, comments that you would hear from people around you, you kind of thought, 'Oh, I don't know. I don't want to play up that part of myself so much.'

This is a useful illustration of how insidious homophobic attitudes proved to be, especially in the family where they may be voiced simply in passing by authority figures whose beliefs are valued by children around them who may not yet know otherwise.

Ultimately, the work of the family in enforcing an environment hostile to homosexualities in the lives of these men was done both overtly and covertly, through force and language. For Jorge, such an environment still exists between him and his family. He continues to face rejection because of his sexuality and recalls being physically abused by his family on a trip back to Portugal, and feeling his life threatened upon discovering an effigy on his family's porch with a rope around its neck. Gilberto and Alex do not speak about facing such extreme 
forms of homophobia from their families, but do recall their sexualities acting as a barrier

between themselves and their families to varying degrees after coming out. Gilberto explains:

So for about a month they kind of kept their distance. But eventually they came around and they never talked about it anymore. I never really talked about it anymore. Although over the years I had women lovers after that, for a period of time, but I also had men lovers and they were aware of both of them so they obviously saw me being involved with men and women, and lately more so with men...But it's not a topic that they bring up or I bring up. But it's just sort of there.

Although Gilberto's coming out did create a bit of a rift between him and his parents for a short while, they continue to maintain a relationship today with a seemingly unspoken agreement that his sexuality does not need to be overtly discussed. Alex's sister had a similar reaction to his coming out, but one that has significantly altered their relationship. He says:

My relationship with my sister completely changed when I came out to her. And it's been strained, and it still is to this day. And that was twenty-something years ago. And we were tight, we were good friends... When I told her she covered her face, she didn't want to hear it, she didn't want to talk about it...And we never talked about it again, to this day.

He has been able to maintain a healthier relationship with his mother, but it did take a while to arrive to where they are now.

I've brought my mother around. She's really come around. She's to the point where she thinks it's okay to give me advice on my romantic life. Like, no. But that's what she does to my brothers and sister so it's normal, right. So it's good, yeah. It's a lot better than it was. But we didn't speak for years. We didn't speak for years and the "gay" thing was a big part of it.

...My Portuguese mama who still takes care of me to this day. She's turning 80 this month, she can barely walk, but when I go over, man, there's like 3 days' worth of food that she's made for me.

It is important to recognize then that some of these men have been able to maintain relationships with their families despite initial challenges that emerged after they revealed the nature of their sexualities. While it has certainly not been easy or instantaneous for most, this research suggests that some Portuguese gay men who grew up in the '70s and ' 80 s have been able to find some level of acceptance in their families today. 
Trevor's experience stands-out as relatively unique here because he was more able to enact his sexuality in different ways around his father while growing up. His father grew progressively ill throughout the " 80 s so Trevor delayed his entry to university to stay home with him as a caregiver at just 18-years-old. On a trip to a private clinic in California with his dad, Trevor met someone.

I met a man in his 30s. And he was an aspiring actor, as all people are down there. $\mathrm{He}$ gave me an $8 \times 10$ glossy to take home and he wrote an inscription on the back...I think my dad was suspecting something at this point, right. I said, "Dad, I made a friend!" I showed him the picture. He looked at it and read....what he said. Oh no!

He said, 'Hmmm.' [Trevor laughs]

While not the most encouraging response, it is significant that Trevor's father did not respond negatively either, and did not try to discourage any suggestions of homosexuality in his son. Around the same time, Trevor also met his first boyfriend, and would spend time with him at home while his father was present.

He used to come over, we used to disappear into my bedroom...We'd spend hours in there, having sex or whatever, and then we'd come out, go to the bathroom, he'd be there. Here I am thinking he would never know...But then, of course he knew. I just spent three hours in the same bedroom with a boy. He never said anything.

Although it is true that Trevor's father did not try to discourage Trevor's sexuality in any way, hints toward such a sexuality were responded to largely with silence. Such a reaction is similar to the ways Gilberto's parents and Alex's sister have responded to their sexualities. While the sexualities of these men are seemingly accepted by their family members, there remains a taboo element to homosexualities that precludes them from open conversation with all members of their families.

Trevor debated whether to come out to his father before his passing, ultimately choosing not to. However, he does think his father would have eventually embraced who he is. $\mathrm{He}$ 
remembers that there was a "progressive side" to his father, who was well-educated and wellread. He explains:

I thought actively about coming out to him. He found, one day I was crying, I was just upset about this whole issue. And he found me, I was crying. He said, 'What are you crying about?' And that could have been my opening. But I chose not to tell him...there was that side to him but I think he would need time, and he didn't have the time. So I chose not to come out to him

Trevor's fear was that his father may react negatively to his coming out and that his sexuality would act as a barrier in their relationship, as it did for other participants in their own families, but in the late stages of his father's life before he was able to come to accept it. The risk that his father may pass away while such a rift remained between them was not worth taking. For Trevor, keeping silent and continuing to hide his sexuality was the surer option.

To be sure, family members of other men interviewed here showed their acceptance and support in explicit ways as well. Alex felt comfortable enough to come out to his older brother in his early-20s, and that brother proved to be a significant source of support and inspiration for him throughout his life. "He was very supportive and understanding," he explains. Adriano’s father refused to hit his son anymore once he asked Adriano to explain the situation and the reason his mother was upset with him, and even defended him from his mother in the years that followed. He recalls one telling interaction that occurred after the fight with his mother outside of the bathroom (p. 38):

Later on that night my dad came up to speak with me and he's like, "I don't understand what's going on. Your mom wants me to hit you, I don't want to hit you. Explain it to me." So I just looked at him and I said, 'Dad what you have with mom, that's all I want. Forget about the bodies. The feeling you have that you want to be with someone, together for the rest of your life, that's what I'm looking for. Same as you. It's just going to be with a guy.' And funnily enough he just sat there, he took it in. And then he's like, 'Okay. Alright.' And then that was it. He's never laid a hand on me since.

And then when my mom was giving me grief, like egging me on or something, he would come to my defense. Which is kind of funny. Because I always think it's the mom who's more protective of the gay son than the dad, but no, in my case it was the dad. 
It is thus important to note that there is no one way that Portuguese families in Toronto responded to a gay son or brother from this generation. These responses vary from case to case, and differ inside families themselves. What this research highlights is how some members of this community understood homosexualities at this time and what influenced such understandings. It also shows how some of those involved responded to them. Future research in this area should do more to capture the range of possibilities in these experiences and identify prominent trends among them to more confidently speak to how much acceptance Portuguese gay people have found within their families and further detail what that process looks like.

\section{In/Visibility}

It is useful to go back at this point and examine why other participants felt compelled to keep their sexualities hidden while they were growing up, adopting the invisibility surrounding homosexuality in the Portuguese community as their own, and consider some of the ways in which they did so. With such a foundation, we will be better equipped to ask how and why the Emanuel Jaques murder and the moral panic that followed affected these men, and better able to comprehend how they emerged from such an environment.

Adriano started to discover his attraction to boys from a young age, but knew that such an attraction could not be expressed. He explains:

I would say more around 10 where I was starting to feel more of a difference towards boys than girls...I didn't know what that difference was, but stifled it because, given that whole religious thing growing up.

Even though he did not yet fully understand such an attraction, he did know that he was unable to express it because of the value systems around him. Adriano's choice of words here is notable. To "stifle" something is a conscious and trying effort - more difficult than simply hiding something and eventually forgetting where you put it. Think about stifling a cry: although the cry 
may not externally manifest, as long as the sensation is present, the would-be crier must work to keep it hidden. While the emotions motivating such a cry may dissipate, it is extremely unlikely that same-sex attractions can ever fully dissolve in those who harbour them. Stifling a sexuality is thus a consistent and concerted effort. For a 10-year-old to be sensitive to this pressure before fully understanding what such a "difference" in how they felt towards boys versus girls even meant illustrates how powerful the homophobic attitudes a young Adriano had already encountered. A child facing an attraction to a person of the same-sex does not inherently know that that feeling is something to be stifled. They must build such an understanding by witnessing an environment where it is deemed wrong.

Like Adriano, Jorge also discovered his sexuality at a young age. Although he recalls privately being sexually active with other boys and men in his early- to mid-teens, he was unable to openly express his sexuality until he began visiting gay bars in and around the ChurchWellesley area, what's now more popularly known as the Village, and connecting with other LGBTQ2+ people. Even then, Jorge often went out in the cover of night and was sure to remain vigilant.

I remember going to bathhouses at 17, 18-years-old. It was scary. To get in, before we looked in the streets seeing if anybody was seeing us. We walked up and down, and then we would walk in.

Alex had a similar experience when he ventured out to bars in the Village several years later.

And the first couple years of going out to the bars, Colby's and Comrades and Chaps back then, sometimes we would circle the block two or three times to make sure that nobody we knew saw us go in there.

These acts of vigilance and avoidance point to the weight of the real and perceived risks that came with having one's sexuality visible in public and being marked as homosexual at this time. Alex makes this explicit: 
Even if there were times when we could be out and comfortably out and confident and everything but in some places it wasn't okay to be gay. And you had to butch it out...Anywhere on the street it was not okay. Absolutely anywhere on the street it was not okay. And public transit. When we were in public it was not okay...It was okay in privacy, or in dark places.

For Alex this meant negotiating his identity in such a way that when he had to "butch it out," the nature of his sexuality could become imperceptible, or read as entirely heterosexual. In other words, he had to learn how to make his sexuality invisible when necessary by deemphasizing any behaviours that may be read as feminine or threatening to normative notions of a masculinity that proved hostile to homosexualities. Not doing so successfully could lead to significant emotional and physical harm. Presumably heterosexual men, for example, could interpret mere looks as homosexual acts. Alex recalls:

I remember being on the Dufferin bus and if you looked at a guy for a nanosecond too long, you just, your eyes are shifting, whatever...'What the fuck are you looking at!?' Really? Like you're on the bus man, chill out. Wow. But that was a thing, you know. It was a thing.

Gilberto had a similar experience after a night out. He explains:

I guess this might have been two o'clock in the morning...And I kind of glanced at a couple of guys that were passing me, and I guess my eyes kind of did something from one to the other, I don't know. But they just turned around and they followed me. They literally followed me. They didn't taunt me, they didn't say anything. But they followed me for a block or more. And I felt threatened by them because I felt really targeted.

While Gilberto cannot be sure that he was targeted because of his sexuality, he does believe that to be the case.

They probably just saw me as some kind of gay guy, whatever it is, that they were going to beat up... and teach him a lesson...so maybe they saw something in the way I was walking, I don't know, the way I was dressed. I mean, it's possible that they saw something that they thought, 'Fag,' whatever it is, like, 'Oo he's checking us out.'

Adriano remembers going out with his friends and hearing homophobic slurs thrown at them by people on the street if some of them were acting too flamboyant, or even getting chased after. In 
an effort to deflect attention away from himself in such an environment, Trevor learned to alter his behaviour from a young age around particular kinds of men.

I cultivated a sense of fear of...certain kinds of men. The jocks, the athletes, you know, that kind of - I couldn't deal with them. So I learned the art of avoidance. One way of surviving as a kid is, of course, becoming small. Making yourself unnoticed. Pulling back. Knowing how to avoid things. Talking your way out of things.

The fact that participants remember feeling vulnerable in public because of their sexualities, specifically around men, confirms that Portuguese gay youth were sensitive to the hostilities faced by LGBTQ2+ people all over the city at this time. The oftentimes-violent displays of homophobia outside of St. Charles Tavern where LGBTQ2+ people in the city would head for Halloween, some dressed flamboyantly or in drag, stood out as one example for Jorge as one source of this fear. It is thus inaccurate to suggest that these men were not influenced by factors outside of the Portuguese community as they came to understand their sexualities - even if other members of the Portuguese community could be defined as "global villagers." It is also another instance where sexuality intersects with gender. The aggressors participants recall fearing are men, and that fear often hinged on one's ability to stifle any expressions that could be seen or understood as revealing of a homosexuality by moving outside normative expectations of what a man looks like and acts like. Those expressions were instead largely relegated to private spaces. The adoption of more traditionally masculine ("butch") forms of gender expression thus allowed some participants to obfuscate their sexualities, and also satisfy familial pressures. Gilberto, whose father was a carpenter, recalls being expected to take up a similarly "masculine" line of work like construction or architecture after high school. Sensing his interests were elsewhere he decided to go to the Ontario College of Art and Design (OCAD), an art school in Toronto. 
The program I got into was Industrial Design because I felt like, 'Okay, I'm going to go to an art school but I'm going to do Industrial Design - it sounds kind of butch and everything.'

While his choice of school may have been read as overly feminine, due to the links drawn between femininity and the arts, Gilberto's choice of program reassured the pressures he felt to pursue a more masculine vocation. Interestingly, Gilberto felt out of place at OCAD because of how he was pushed to present himself in a traditionally masculine fashion by his father.

I looked different...My father forbid me from wearing bell-bottoms, my hair had to be like this all the time, nothing ever long. All the other kids had long-hair, they were all in their jeans and beads.

Gilberto essentially found himself compromising on his education to satisfy the expectations that being a Portuguese man entailed in his household, but unable to fit in with who he called the "cool kids" at OCAD as they more freely experimented with gender. Ultimately, Gilberto left the program to study photography at Ryerson University.

Even though Alex knew he was attracted to other boys as a teenager, he responded to similar pressures, in part, by dating women.

I dated girls but I always knew. You just dated girls because that's what everyone did and it was expected and it just kind of happened. But I always knew.

In doing so, Alex made a conscious choice to satisfy those expectations placed on young boys and men by enacting a normative heterosexual identity, even though he knew that it did not align with his own self-images.

Similarly, Adriano remembers feeling pressured "to act straight," and "to hide who I was," as he puts it, especially in and around the church and in view of his parents. He explains:

You go to church all dressed up [laughs]. No jeans in my day. You go all dressed up and you certainly don't act flamboyant. And even out of church, you know, when the mass is out and everybody congregates in the front of the building and talks and stuff you still have to be, you know, straight. 
Like I wouldn't hug my friends in that scenario. I would hug my friends when we were out of the church area. Like meeting them personally, hanging and hugging my friends who were boys. But never to do that in front of parents or their parents or anything like that.

For a young Adriano, acting flamboyantly or even hugging his friends was off-limits in view of his parents or theirs because of the fact that they were also boys. Implicit in this recollection is Adriano's understanding that certain mannerisms, behaviours, and forms of physical contact between him and other boys might have lead to questions about his sexuality at a time when he was not ready to reveal that part of himself.

It would be inaccurate to suggest that all attempts at hiding one's sexuality were conscious attempts at negotiating a marginalized identity. Gay folk in the Portuguese community undoubtedly internalized some of the negative attitudes and fears surrounding homosexuality that they encountered. Although Gilberto felt that in the '70s it was becoming more acceptable to identify as bisexual, he struggled with the idea that he may be gay.

I sort of felt like, 'It feels okay if you are kind of bisexual. It feels okay if you love a guy, it's okay. And if you love women, it's okay.' You know, just being gay-gay, solo, didn't seem to me, it seemed like, 'Well I don't know how that's going to fit-in.' I'm not sure, like I really struggled with that one. I kind of wanted not to be just gay-gay; gay $100 \%$.

Gilberto recognizes that "a lot of that was sort of a reaction to AIDS." He explains:

When ' 82 , '83, came along, as I'm starting to feel more comfortable about being gay, suddenly, it was about mid-80s when it got really kind of scary, but it was kind of like, "Oh boy." You know, suddenly it wasn't so cool, the idea of being with guys because it was kind of like, the time when, very early on people didn't even know what AIDS was and how you got it, and how deadly it could be or not be...It was a time when I really was super paranoid about sex with guys.

Of course, these men did not grow up behind a wall separating them from the rest of society.

Those old enough to understand the AIDS epidemic, like Gilberto, shared the fears present in the LGBTQ2+ community, and they served as another obstacle in the enacting of homosexualities. 
These efforts to stifle or make invisible parts of oneself, or create and emphasize others, ultimately require one to force spaces between the frames of one's identity. Jung and Hecht (2004) conceptualize these fissures as identity gaps. This requires the personal frame of identity, and an understanding of one's sexuality that exists within it, to be suppressed in such a way that that sexuality cannot be easily perceived in how one enacts their identity or in how one relates to others. Participants were thus unable to openly enact their sexualities, or connect with other LGBTQ2+ people and communities. Participants surveilled the ways they acted, careful not to act too "flamboyantly" and willing to "butch" it up when necessary in order to perform a normative form of masculinity that could conceal a non-normative sexuality. Unlike the inevitable gaps that may occur in communication between two parties who do not share the same experiences, backgrounds, and a basis of understanding, the identity gaps observed here are significant because participants intentionally placed them in order to keep a portion of their identities invisible. By their nature, these gaps are unstable and require regular tailoring to fit any particular situation at any particular moment. Their maintenance can prove difficult and tryingespecially while fulfilling one's desire for love, sex, and community and retaining a connection to the people and communities that may make it difficult to openly express a homosexuality. Some, if not all of these desires must be rejected to maintain these gaps.

This is not to say that young Portuguese gay folk were not also pushing the boundaries of their environments when they saw opportunities present themselves. As a part of the Goth scene, Trevor had grown long hair, sometimes styled in a mohawk or crimped, and wore makeup and tight clothing—inspired by artists like Boy George, Siouxsie Sioux, and Duran Duran. A memory of one night when he was getting ready to go out dancing in a "feminine-Goth" look is particularly telling. 
I went down, and I can't believe I did this, my dad was just watching TV in his pajamas and I said, 'I'm the daughter you never had.'

...He looked at me and he said, 'Okay.' And he just went back to watching television. His father's response was unlike those we may predict from other Portuguese men of this era, considering what we know about dominant ideas about gender roles and expectations in this community. Even still, Trevor's gender-bending is noteworthy in its rejection of heteronormative gender roles and expectations. Adriano and his group of friends, sensing a safety in numbers when they were together around "big tough dudes," acted out in their own ways. He remembers:

We were kind of rebellious 'cause sometimes we just acted more gay to get guys going. Some of these men were also cautiously seeking ways to express themselves sexually, even before they were "out." Jorge was going to bathhouses in his late-teens, and he was also active in the cruising scene in local public parks after dark. Trevor posted a classified ad in a local magazine in the late ' $80 \mathrm{~s}$ in an effort to meet people. He explains:

So before the internet you put an ad, those personal ads, in, it wasn't XTRA, it was NOW Magazine. I remember having to go to their offices, you pay for a box and they give you a pile of letters. And then I went to a cafe to read them all. That's how I met some people. Actually that's how I met my first boyfriend.

It is therefore wrong to suggest that all young Portuguese gay men perfectly assimilated to normative ideas of heterosexuality and masculinity in an effort to make their sexualities invisible, despite the pressures to do so. In fact, some were actively pushing back against these ideals to make space for their own expressions of sexuality and gender when possible—even if done covertly and with some trepidation.

Ultimately, it is difficult to define what it meant to be Portuguese and gay in the '70s and ' 80 s because such a category was largely invincible to the outside observer, and since the experience of homosexualities in this community was often so personal and dealt with internally. The voices included here suggest that it meant, in part, learning to minimize or alter mannerisms 
and behaviours that could be read as "gay" and actively assessing public and private situations due to legitimate fears that such a reading could result in rejection, judgment, or physical and emotional harm. This required the creation and maintenance of identity gaps that obfuscated the personal frame of identity in the ways these men were able to communicate their identities and relate to others. 


\section{The Murder of Emanuel Jaques}

The kidnap, rape, and murder of Emanuel Jaques in the summer of 1977 at the hands of three men deeply affected Portuguese gay men growing up during this time in ways that have not yet been explored. The murder and the intense moral panic that followed is an extremely useful case study to examine here as it is the first time the city's Portuguese community and homosexual community converged in the public eye. The murder ignited fear, confusion, suspicion, and even guilt in the lives of those interviewed here.

Soon after the news broke, homophobic sentiments were being explicitly and implicitly voiced by the city's Portuguese and State representatives, brought to city streets in protest, and printed in the mainstream media. Jorge summed up the tone of such a response:

Right away, 'Os paneleiros, these faggots,' you know, 'They killed my son. They killed our community. They destroyed a child of the Portuguese community.'

As folk devils identified in the moral panic, the entire homosexual population were made suspect in the crime - the ambiguous "they" that seemingly destroyed a whole community along with an innocent child. The men interviewed here did not feel the brunt of such a classification, likely because they were not yet openly identifying as homosexual, but were affected in different ways as Portuguese homosexuals. In the wake of such a panic, Jorge, Gilberto, and Adriano were pushed to question the nature of their sexualities, developing fears of others and even internalizing the panic's assertion that homosexual men posed a significant threat to children. Alex and Trevor, both young children when Jaques was murdered, remember learning about the event later, and begin to illustrate the legacy of such an event in the lives of Portuguese gay people. 


\section{'A loss of innocence'}

Prior to the murder of Emanuel Jaques, Jorge remembers the Portuguese community feeling comfortable in their new surroundings. He explains that they were able to establish several clubs and community churches, and express their culture and practice their spirituality in city streets free from discrimination. "We thought Canada was a safe place," he says. That changed when a 12-year-old Portuguese boy, in many ways just like all other Portuguese boys in the city, was lured off the streets where he was shining shoes at Yonge and Dundas, raped, and brutally murdered in one of the city's most publicized crimes of the '70s. Jorge explains:

When this happens it's like a knife going into the heart of a mother, of a brother, a nephew, a friend, a community.

Gilberto echoes this notion, classifying the event as a "watershed" moment that seemed surreal. He remembers:

It was a very sad time and it just felt like a loss of innocence occurred right there for everybody.

For a number of Toronto's Portuguese, the murder of Emanuel Jaques was felt personally, and as an attack on the entire community. What differentiates the experiences of participants included here from that of other Portuguese in the city is their simultaneous struggle with sexualities that were, in many ways, at the center of the moral panic. Their experiences speak to the unique position that they were in as the Portuguese and LGBTQ2+ communities clashed.

\section{A Fear of Self/Others}

Jorge, Adriano, and Gilberto, who were 15, 11, and 20 at the time of the murder, experienced this loss of innocence first-hand - fearing that the Jaques murder was representative of what may come to them, questioning if they may develop urges similar to those that his killers had, or acting as a significant obstacle in their own coming out. Ultimately, their innocence as 
developing sexual beings was also taken away or thrown into question as a result of the murder and the panic that followed.

Jorge was particularly affected by the murder because he was having anonymous sexual encounters with other teenage boys and men at cruising spots in High Park and Trinity Bellwoods Park at night around this time. He explains:

I was thinking, you know, 'Are we all going to get abused like this? Is that what's going to happen? I meet a man at High Park, or a park. Am I going to get chopped too?' We were frightened. We couldn't trust anybody.

By drawing connections between his own sexual experiences in secluded areas of large parks and the murder, the fate of Emanuel Jaques at the hands of extremely troubled men in private proved to be a significant source of fear for Jorge. His memories of Jaques' funeral are particularly telling here:

I could believe that I was inside that coffin. And when I said bye to Emanuel Jaques I said, 'I'm with you.'

In effect, the murder of Emanuel Jaques presented itself to Jorge as emblematic of what being gay in Toronto could mean for him. Ultimately, he felt that his life was in jeopardy as a young gay man.

His death made me feel even more confused with my life. Wondering if everything, everybody would be the same, like his killers.

Jorge internalized the narratives of the moral panic that painted homosexual men as dangerous by nature of their sexuality, and adopted a fear of other gay men in his own life.

Similarly, Adriano internalized the fear that gay men pose a threat to children into the personal frame of his identity, pushing him to question his own self-images. He explains:

As I watched the news I found out it was these men wanting to rape him and then of course I started to question, 'Okay well is this going to happen to me? Am I going to change into some sort of monster?' You know, I knew I wouldn't but that thought gets in your head. Like, 'Is this what's awaiting me? Is this some sort of urge that's gonna get me?' 
Even as an 11-year-old boy Adriano was acutely aware of the murder. He and his family would pray the rosary aloud every night with a picture of Jaques in front of them at this time. The murder "just kind of shocked my world," he remembers. "I didn’t understand it." Without anyone available to turn to with these questions who he thought would be accepting of his sexuality, Adriano was left vulnerable to a dangerous line of questioning about what his future might have looked like. His learned knowledge of homosexuality as a "sin" and an "evil" presumably confirmed false narratives of homosexual men put forth in the panic that morphed into his own self-questioning.

Adriano also developed a fear, one "egged on" by his mother, of Yonge Street because of the Jaques murder.

I grew up with that fear of, 'This kid was murdered, Yonge Street is horrible, it's got bathhouses and bathhouses are horrible,' and you know, all that stuff. It was a fear. Here we see how the murder could get so easily wrapped up in expressions of sex and sexuality completely unrelated with the crime. Although bathhouses did not play a role in the Jaques murder, the panic that it inspired painted with a broad brush that enveloped other sexualities and sexual expressions that differed from the norm. Adriano's fear of Yonge illustrates how powerful the "clean-up" campaign was, and how it affected young gay people as well. He continues:

Then it went into my late teens, early-20s with my Portuguese youth group. We would go down to Yonge and the first few times man I was like, 'I don't know. I don't know. I don't want to be here. It scares me.'

When asked for clarification, Adriano notes that such a fear was ignited as a direct result of the Jaques murder. He says:

Before I never even heard what Yonge Street was. That's what sparked everything. While the fear did not last much longer after Adriano had seen Yonge Street for himself, it is clear that the narratives built up around Yonge in service of the "clean-up" campaign directly 
after the Jaques murder had a lasting effect on him. This points to how potent a moral panic, especially those bolstered by political agendas mobilized in the mainstream media, can be — even on those who may be counted among its folk devils.

Gilberto remembers significant fears tied to his safety in the city emerging in the wake of the Jaques murder as well.

It just seemed to hit home that the world was a more dangerous place than we realized, especially coming from a small town in Portugal where people would not close their doors at night.

As he suggests, this murder affected Portuguese people in Toronto so deeply in part because of how starkly it differed from their own experiences growing up in rural villages where personal safety was rarely questioned. Like Jorge and Adriano, this fear grew larger when Gilberto took his sexuality into account. "It was frightening and it, sort of, threw a wrench into my own feelings of where my place was as a sexual being in this world" he explains.

It was kind of like, 'Oh, there's gay stuff in there too,' right? 'And it's a boy. They murdered a little boy and they abused him sexually,' so it was, 'Oh, it's kind of, it is like a homosexual thing, it's a gay thing.' And it's, 'Oh, that's gonna really not look good in the context of me coming out to my parents.' Like, 'Are you a pedophile? Are you like that? Are you...'

While Gilberto is clear that he did not personally see the murder as a "homosexual crime," or the murderers as representative of himself or other gay people, it is apparent that he does not believe that everyone else shared his perspective.

I just thought, 'Well, if I'm a man, and I have sex with other men, people potentially extrapolate and sort of see it as another crime in the same way.'

In effect, the Jaques murder introduced a fear into Gilberto's life that he may be cast alongside those who murdered Jaques because of his sexuality, and see his ascribed relational identity defined along those lines as a folk devil. This effectively changed the ways Gilberto was able to express his sexuality, as well as the ways he saw other people. 
Did it change the ways I could express my sexuality? Well, given that it had a sort of chilling effect upon my attitudes towards people and towards sexuality, I guess it did. It sort of made me more reserved and more cautious and more conservative.

Although the murder did have a "chilling" effect on Gilberto and the ways he could relate to people, he did go on to share an apartment and a romantic relationship with a man a few years later.

The fear that the Jaques murder ignited in Jorge's life manifest in more severe ways. Jorge remembers feeling suspicious of the gay community for a period of time after the Jaques murder.

When I heard he was abused and killed that made me feel frightened, horrible. And at one point I couldn't trust the gay community because I was convinced it was the gay community.

These suspicions, Jorge explains, were due to George Hislop's name being reported in news stories surrounding the crime. As someone who struggles reading English—a struggle relatively common in the Portuguese community at this time - it is understandable that Jorge could see the connections being drawn between the murder and homosexuality, along with the public furor, as an indictment of the homosexual community as a whole.

Jorge attempted to reject his sexuality in response to the fears and suspicions that the Jaques murder inspired in him. He explains:

I dropped the sexuality and got married because I was scared. Because at that time when I got married at 19-years-old, gay, it was scary to be gay.

Jorge believed that dropping his sexuality would quash any fears about what he could have faced had he continued to enact his sexuality or be defined as a homosexual. These fears were compounded by the pressures to marry that he felt from his parents, some examples of which he recalls summarized as the following:

'You must be a man! You must get married! You must have a child because we want grandchildren.' 
Despite a warning from an aunt who had at this point discovered the nature of Jorge's sexuality, the wedding continued.

My aunt, my mom's sister, called my wife the day before I got married. 'Don't marry him, he's a faggot. E paneleiro.' She married. She didn't believe. Because I knew how to hide it so well.

However, entering into a heterosexual marriage proved unsuccessful and the marriage ended after two-and-a-half years. No other participants included here recall rejecting their sexuality in a similar way, but Jorge's experience is nonetheless noteworthy. It is an extreme example of how far young men in this population could be pushed to go in response to the Jaques murder, the panic that followed, and the culture that surrounded it. The identity gap that emerges here is a formidable one, effectively limiting Jorge's ability to authentically enact his sexual identity and build meaningful relationships with individuals that he was attracted to. It also compels us to remember those who are still feeling pressured to reject their sexualities and are thus not represented in the interviews collected here. While certainly a difficult task, future studies should seek out these stories and shed light on the experiences of these individuals as well.

\section{Looking Back}

It is important to acknowledge that not all participants included here have clear memories of the Jaques murder. While it did receive a significant amount of news coverage, it is incorrect to assume that everyone was tuned into every development in the case - a trap that we may easily fall into when doing focused research into a singular event such as this one. That does not mean, however, that the engagements Alex and Trevor had with the murder and the issues it raised years after it occurred are not useful here. Their perspectives emerge from more of a distance than those Jorge, Adriano, and Gilberto offer and thus do not capture the same firsthand quality of their experiences. They do, however, give us a sense of how young Portuguese 
gay men discussed the Jaques murder with one another where such a community existed, and how it may have stirred homophobia in the family. They also introduce a critical homosexual reading of the cultural response it spurred.

Alex, who was only 8-years-old at the time of the murder, could not recall the summer of '77 with much clarity. However, he does remember it brought up later on multiple occasions in the youth group he was a part of with Adriano at the community church by those who were in their teens when the murder occurred. When asked what those conversations were like, he says:

Just, "Be safe," I think was what I remember. I do remember having a big conversation then and a lot about the difference between being a pedophile and being gay. Which is not, it's nowhere near as much of a problem to explain the difference to people now as it was then because it was the same, the same thing. In French the slang word for gay is pede, and where does that come from? Pedephile, right.

Such a recollection is important to recognize because it shows that young Portuguese gay people were sensitive to the conflation of pedophiles and homosexuals, and the belief that homosexuals pose a threat to children. It also gives us a sense of how they confronted such notions, and points to how prevalent these beliefs remained years after the murder. It is clear that in this particular community of young Portuguese gay people, the older members of the group took on educator roles for the youngest among them, like Alex. However, Alex's experience proves unique since most of the men interviewed here did not have any support system to rely on when facing the issues that the Jaques murder raised.

Trevor, who was also 8-years-old at the time of the murder, cannot clearly remember that summer either. He does, however, remember several incidences of homophobia within his family following the murder. He explains:

There were a few really homophobic incidents in my family that I remember from my very early teens. So this would have been after the Jaques murder, so between ' 77 and '84. 
While he cannot confidently trace these incidents back to the Jaques murder, he does think it "ramped up the homophobia." In recalling some of these incidents a pattern emerges for Trevor, who notes that several had to do with relationships between homosexual adults and children, like a discussion with a cousin about gay men adopting children that quickly turned sour and hostile. Trevor has since separated himself from his family, in part, to get away from their persistent homophobic beliefs.

\section{A Critical Eye}

Participants included here also share critiques about how the gay community responded to the murder in one particular case, and how this period is remembered and represented in the Portuguese community more recently.

Gilberto remembers taking issue with Gerald Hannon's article “Men Loving Boys Loving Men," published in Issue 39 of The Body Politic just four months after the Jaques murder. He explains:

So that didn't seem like it was a, it wasn't a healing perspective or analysis or response, or, you know, after-effect of the whole thing...I didn't feel like it was a positive occurrence.

While not an uncommon critique, it is notable here because it illustrates that Portuguese gay men who were moving into adulthood at the time of the murder were informed about the responses from the gay activist community — even if it was from afar. This is significant because the apparent lack of Portuguese representation in early gay organizing in Toronto may suggest that these individuals were not engaged. It is entirely possible that because of the cultural climate this particular group faced in living with a marginalized sexuality it proved extremely difficult to openly engage with the gay liberation movement. As Gilberto makes clear, however, that does not mean that they were not aware of what was occurring in the gay community at this time. 
Trevor learned about the specifics of the murder and the ensuing panic several years later while doing research into gay and lesbian history during his undergraduate education. While he recognizes that the cultural response to the Jaques murder marked, in part, an important moment of civic engagement for Portuguese people in the city, he is also extremely critical of such a reading. He cautions us against accepting this reading as the only way to understand this response, as he believes Bill Moniz (2006) does. He suggests:

I think he misses out on the kind of hate-filled, demagogic populist intolerance. It's like a mob, really. A family mob, right.

This perspective is not one that is voiced by others included here, but it is important to consider because of how significant the Jaques murder and the reaction that followed remains in the history of the Portuguese immigrant community in Toronto. It is crucial to remember that a number of the protesters inspired by the Jaques murder took to the streets to call for harsh state interventions into the lives of sex workers and sexual minorities because of the actions of a very small number of troubled individuals in these groups. Trevor argues that understanding this moral panic as merely a moment of civic engagement missies this point and fails to address the dangerous ways of thinking it exposed.

It's this recapitulation of incredible amounts of homophobia and uncritical attitudes about Portuguese immigration and belonging in Toronto which is heavily influenced by very normative, hegemonic, heterosexual masculine family — patriarchal family values.

Highlighting the negative consequences of such a panic and the value systems behind it, as we are doing here, gives voice to some of those individuals who suffered under them and introduces a new way of understanding this moment of time as one that had significant negative impacts in the lives of gay Portuguese individuals. 


\section{'I feel part of that death'}

The most surprising finding uncovered in this research is regarding the guilt that Jorge shoulders because of the murder. At 11-years-old Jorge was sexually abused in the church by a man who worked there.

But you couldn't speak about it. Sexual abuse was in '73, '74. [Jaques] died in '77. If we spoke about that in '73, '74, I think there would be an alert in the families, in Portuguese families. Because we were sent to the church...and mom thought that was a safe place. So at the time if this happened in the church it could happen somewhere else. So why didn't we speak about it?

Evidently, the environment restricting these men from speaking about and expressing their sexuality as they were growing up in the Portuguese community also extended to Jorge's experience of sexual abuse. This is further complicated in a community where the Catholic Church is so prominent. It is entirely possible that Jorge's traumatic experience could have been subject to doubt and his family ostracized had it been publicized at the time. Nevertheless, Jorge has internalized this enforced silence as a fault of his own. He explains:

I feel part of that death. I feel part of that misery.

Such silence did not only preclude Jorge from any kinds of formal support at the time, it also allowed this guilt to grow unchallenged and tarnish his conceptions of himself. While this experience is unique amongst participants included here, Jorge's feelings of guilt illustrate just how damaging the push into silence can prove to be. In this case, it also obscures its nature as an external societal pressure by seeing Jorge take responsibility for said silence upon himself even though he was just a child, and a victim of an incredibly traumatic experience.

\section{Years On}

The fact that the Jaques murder occurred over 40 years ago proved to be quite demanding for participants in this research—especially those who were not yet in their teens in 1977. In 
trying to uncover a Portuguese gay perspective on the murder and the moral panic that followed in the absence of any published work to date, we must rely on the memory of individuals who were present. These primary memories, as Plummer (2001) would term them, are no doubt difficult to recall 40 years later, and may vary from the original experience they are based on or when recalled again later. They are also shaped and reshaped by external factors like setting, society, and culture, and are actively constructed in the process of remembering and retelling (Plummer, 2001). It is thus more useful to focus on the emotions and associations captured in these recollections rather than their particular details because these emotions and associations tell us how these events may have affected these men, rather than just what they might have observed. These perspectives are thus to be understood as participants' subjective recollections and interpretations of a particular historical moment rather than a historical truth. In other words, these are their personal truths. They are most effectively understood through the interpretive paradigm of life stories where the aim is to develop an enhanced understanding of an experience and social landscape from subjective memories, "giving flesh and bones" to issues that are not thoroughly understood only from afar (Plummer, 2001, p. 248). The implications of such stories remain clear. Young Portuguese gay men responded to the Jaques' murder and the panic it caused with fear, not only for their own safety but for how they may mature as sexual beings, confusion and suspicion, and, at least in one case, guilt. 


\section{A New Way}

One question continues to stand-out at this point: how did Portuguese gay men navigate through the obstacles that restricted them in developing and enacting their sexualities in the ' $70 \mathrm{~s}$ and ' 80 s to emerge at a point where they are more able to do so today? As moral panic theory reminds us, panics activate fears that have laid latent in a particular population (Goode \& BenYehuda, 1994). As such, the Jaques murder did not create the negative attitudes surrounding homosexuality in Toronto's Portuguese community, but it certainly did not eliminate them either. For some, such a state was heightened by the murder, and this research shows that it had already existed before it, also persisting once the panic settled. "Even up until the beginning of the '90s people were frightened to be gay in the Portuguese community," Jorge explains. For participants growing up in this community, the careful negotiation of an identity where one's sexuality was, in many ways, at odds with the beliefs and values so prominent around them proved necessary. Each participant ultimately discovered different paths of access to the Portuguese and LGBTQ2+ communities in Toronto. Such a project also required defining new ways of being Portuguese in Toronto that allowed for the simultaneous existence of a homosexuality and its expression.

\section{Coming Out}

Participants included here did not arrive at this point in an instant. They all recall coming out in various ways, both voluntarily and involuntarily, and often not all at once. Adriano was outed when his mother found his journal. Jorge's sexuality was uncovered by his family when his older brother found that he had moved in with a male partner. Gilberto's parents asked him about his sexuality when they recognized the prominent gay activist he was living with at the time in the media. Even then, however, each of these men experienced a kind of duality where their sexuality oscillated between states of visibility and invisibility depending on where they 
were and whom they were with. Alex and Trevor give us a better sense of what this was like, referring to their respective coming out experiences as a "process." Alex explains:

My coming out process was years and years and years. I was 18 when I mentioned it to the guys in the group, so I had already known them for a couple years before I came out as gay. But then it would be maybe seven years after that before I came out to my mom.

Such a process allowed Alex to proceed with caution, deeming whom it was safe to discuss his sexuality with at any particular moment in time. He says:

You tell one person first and make sure that it's safe, and then see how they react, and then you tell somebody else.

In effect, Alex had to come out on multiple occasions. In between each occasion, he was required to maintain the identity gaps that concealed his sexuality or risk facing the negative reactions of those who are not so accepting or tolerant. The notion of a "process" reappears in the ways others included here speak about developing and expressing their sexual identities, not just externally, but internally as well. The identities that these men now display did not simply appear, but formed through a process of cultivation and exploration that led to a more holistic identity where their sexualities need not often be hidden or minimized.

\section{Dis/Connecting}

Part of this process meant disconnecting from existing communities and relationships, and forming new connections that allowed for the alignment of each frame of their identity and a more open expression of their sexualities.

For Adriano, disconnecting from the Church proved necessary in developing and enacting his identity. While growing up, Adriano struggled with readings of the bible that deemed homosexuality an evil.

Because I knew I was a good person. I didn't cause malice. I didn't want to hurt anybody. 
Eventually he determined that after thousands of years and multiple translations, the original meaning of certain parts of the bible were simply lost or distorted. However, when he heard that a Pope later came out against gay marriage, telling priests to speak out against it at their own congregations, Adriano could no longer stand it.

So I wrote an email to my family...and I said, 'I am no longer considering myself Roman Catholic. I don't want to go to church anymore. If this guy is mixing politics and religion, I'm out. Why should I be going to an institution over and over that I devoted so much of my time if they're not going to want me. If they feel that I'm less than them, then I'm out. I'm done.'

Jorge, on the other hand, has retained a strong connection to the Church throughout his life. He acknowledges that there are many failings in the Church, but attributes that to specific people, not the religion itself. This is not to suggest that either choice is incorrect, or that one is better than the other. Instead, it shows that each of these men have had to decide who and what they need to align themselves with to live a more authentic, fulfilling life.

Trevor felt the need to push away the Portuguese portion of the communal frame of his identity, one that he found restrictive, to develop his queer self. He defines the effort in the following way:

I felt that in order to be queer I could not be Portuguese. Both by design and by circumstance. So it was an act of will, right? Like it was, you know, first-generation Canadian. A lot of people grow up, they want to separate themselves from their families and strike-out.

Trevor's experience represents the other side of the spectrum where Jorge's choice to reject his sexuality and pursue a heterosexual relationship exists. Both are a conscious decision to reject a part of one's identity that proves to be incongruent with others. Such an incongruence may be because of external factors, like communal and familial pressures to enter a heterosexual marriage and have children, or one's personal desire to more freely express a queer identity being restricted by one's ties to an ethnic identity. Both call upon the forced creation of gaps 
between the frames of identity where sexuality and ethnicity operate, where one or the other is stifled in order for the other to exist. This may be further complicated for some, as Trevor hints towards, by the experience of immigration — one that created hierarchies in the community between those born in Portugal versus those born in Canada. Alex elaborates on this point:

I was born here so I was Canadian. But my brothers, my older brothers and sister, they were born there, they were Portuguese, they were FOBS, they were fresh off the boat, they were immigrants. I wasn't an immigrant.

Implicit in this statement is the fact that a number of Portuguese immigrants did face significant challenges integrating into the city, and in some cases outright discrimination, during this time in Toronto. It was thus advantageous for Alex to be born in Canada and claim the title "Canadian" as his own. To be seen as "Canadian" rather than "Portuguese" meant avoiding being marked as an immigrant, as an Other.

It is understandable why some may have wanted to minimize an ethnicity that was looked down upon and conform to the relative safety of the mainstream while discovering a marginalized sexuality in order to avoid drawing additional attention to oneself. It is possible that the second-generation immigrant, like Trevor, found themselves more able to disconnect from their ethnic identity in order to develop their sexual identity. First-generation immigrants, like Jorge, likely retained more of a connection to their ethnic heritage with active memories of their homeland and thus found it more difficult to reject in favour of their sexuality. This aligns with Sardinha's (2011) assertion that the ethnic identities of migrant offspring are elastic, and can be moulded in certain ways to allow for their inclusion into their surroundings. Ultimately, Trevor took this opportunity to minimize his ethnic identity by forcing a gap between his personal and enacted frames of identity and the relational and communal frames where his connections to the Portuguese community remained to better realize his queer identity. 
For Jorge, this process of dis/connection was initiated when he and his wife split. Shortly thereafter, he met the man he was to spend the next decade of his life with at the bar Cornelius, Guillermo (Gary) dos Santos. He remembers:

That was the beginning of my life. The love story of my life. However, the two felt they had to keep the nature of their relationship secret out of fear of it being marked as a homosexual one - the negative consequences of which they were already familiar with. On a trip back to Açores where Jorge's family had been living at the time, his mother threatened Gary while Jorge was out.

When I went to the city my mother said, 'Vai pagar. You're gonna pay, the sins you're doing with my son. You're gonna die.’

When Jorge found out what his mother had said, he and Gary left, and he did not speak to his mother for years afterwards. Nonetheless, Gary proved to be the perfect match for Jorge, and the two were able to work through their histories as survivors of sexual abuse together. "He was amazing, he was amazing, he was amazing," Jorge recalls. Unfortunately, Gary fell victim to AIDS in 1994. A couple years later, Jorge, who had been living with HIV since 1983, got involved with the support group VIVER, and began holding workshops to share HIV/AIDS awareness and education among Portuguese-speaking people in Toronto. Around the same time, Jorge also joined Arco-Iris, a support group for Lusophone (Portuguese-speaking) LGBTQ people in Toronto that had been established in 1996 by several women (Dupuis, 2002).

I lost my family, I lost some friends, but I gained a lot of friends. I gained a world of friends.

In 2002, Jorge became president of the group.

The emergence of Arco-Iris marked a significant turning point in Toronto's Portuguese community where those Portuguese folk who also identified as lesbian, gay, bisexual, trans, or queer were visibly organizing and fighting for acceptance within Portuguese spaces. One of the 
greatest accomplishments many Arco-Iris members point to is their successful bid to be included in the Alliance of Portuguese Clubs of Ontario (Kenedy, 2012). Jorge explains:

When they called us in and said we had been voted in, it was just, it was turning from dark to a big light.

Beyond visibly bringing Portuguese LGBTQ people together in large number for the first time, Arco-Iris also provided a model for a fulfilling identity where one's ethnicity and one's sexuality could openly coexist — where both could bolster one another. Jorge recalls participating in the Portugal Day parade and the Pride parade on multiple occasions with Arco-Iris. One year they decorated a float to look like a traditional Portuguese house, with laundry strung up outside of it, and the men of the group dressed in drag, like Portuguese women in "moda antigue" (traditional style). To be sure, there were some homophobic remarks.

You know, 'Ah os paneleiros,' you know, 'look at the faggots,' but we just ignored it. Of course, Arco-Iris could not single-handedly eliminate homophobia in the Portuguese community, but its existence did give its members the opportunity to "just ignore it" together, and not in isolation. It provided a way for Portuguese LGBTQ people to participate in their ethnic community without having to minimize their sexuality, instead allowing it to play an integral role in said participation. It also served to bring Portuguese culture to Toronto's Village. One of Jorge's proudest accomplishments is helping to organize an event at Woody's in the early 2000s that featured traditional Portuguese art forms reimagined through drag and traditional Portuguese cuisine. Even though it was held at a gay bar, Jorge recalls several Portuguese politicians and dignitaries attending. Although the group has since disbanded, Arco-Iris members were able to collectively make visible the LGBTQ identities in Toronto's Portuguese community for the first time - the implications of which can still be felt today. Recently the group has begun to come together again. 
Before Arco-Iris emerged in the ' 90 s, the other men interviewed here were already busy forming their own connections that aided in the development of their sexual identities in similar ways. Gilberto's relationship with a prominent gay activist proved to be one path into the LGBTQ2+ community for him. While Gilberto was living with him in the early ' 80 s, he was coordinating Pride events in the LGBTQ2+ community. Gilberto attended a number of them, but as a photographer. This proved to be a helpful way to engage with the LGBTQ2+ community, and that portion of the communal frame of his identity, at a time when he did not yet feel entirely comfortable doing so.

As a photographer you're always an outsider too because you're like a journalist, you're kind of off on the sideline taking notes or taking pictures, so you're not really part of the whole thing...So it kind of protected, I protected myself from being finger-pointed.

It still proved risky to openly identify as gay in Toronto so Gilberto felt it necessary to protect himself from being identified as such. He elaborates:

It was like, you know, you go to some bar and there would be some guys that would ambush you because they knew you were going to the gay bar, and they would beat you up...Like Boots up there on Sherbourne Street, that was one notorious place for that.

So while Gilberto may have been slightly hidden behind the camera, he was still present, and finding a way to engage with a community that he previously could not access. Ultimately, this helped him to minimize the gaps between the frames of his identity that precluded him from openly participating in the LGBTQ2+ community.

In a fascinating turn of events, Alex and Adriano found themselves in their own Portuguese gay community in what began as a church youth group. Alex explains:

There was a youth group and the broader group was more than 40 people. Children and young adults ranging from 12 , maybe, 12,13 , to $20 \mathrm{~s}$. And just by the convergence of the gay gods a whole whack of us turned out to be gay.

For Adriano, the group was a place where he learned that his sexuality was not an evil or a sin, and that he was not alone. He was thus able to create connections in the relational frame of his 
identity that aided in the realization of a more authentic and holistic identity. He explains, "I felt the freest I've ever been with those guys...To me that was like my gay family." The boys in the group explored their sexualities together, curiously watching porn in each other's basements or garages, and discovering their first gay bars with one another. It also served as a place of guidance for some of the younger members in the group. Alex remembers one member who "was always educating us on the ways of the world and telling us about, you know, bathhouses, or this or that...Gay 101, 'If you're going to grow up in this community, these are the things you gotta know." Both remember the group in an extremely positive light. Such an experience, however, was uncommon. Alex notes:

We know, we know, how lucky we were and how unique our situation was because so many other gay people, even other gay Portuguese people that we would meet throughout the years, came out alone and completely isolated

...We're still friends to this day. None of us take that for granted.

As part of this youth group, Alex and Adriano had a safe space to learn, develop, and express their sexualities with people who intimately knew about the struggles they were facing at home and in the Portuguese community. Unfortunately, theirs is not representative of the Portuguese gay experience during this time.

For Trevor, disconnecting from his ethnic identity also meant disconnecting from his family. Such a decision was ratified after a cousin threatened Trevor with violence in the early '90s over Christmas dinner after he voiced his support of gay people adopting children—a threat that went unrepented and unsanctioned by others present. "And I'm the one who's the troublemaker, not him," Trevor remembers. Retaining a connection to his family would require a kind of assimilation to heteronormative notions of sex, gender, and sexuality, Trevor explains, and a tempering of his own beliefs and expression. In other words, it would require the continued maintenance of identity gaps between his personal and enacted frames of identity. Such forms of 
assimilation in familial contexts is one that Trevor sees as a common issue that many gay people have not yet dealt with. He explains:

We need to do a lot more work in changing family dynamics and how people act in them because people seem to think they have a free range in their fucking behaviour with people that are intimate.

An uncritical commitment to the Portuguese family unit is one that pushes Portuguese gay people to censor themselves in familial spaces in an effort to belong, and they become "a whole different person," Trevor argues.

So they have their family life and then they have their gay life, and never the two meet. And they live this - it's not like they're closeted — but they just, there's this dualism, right? And that's something I'm uncomfortable with. Even if they're happy I think they don't know what they don't know, what's possible.

At this point in his life, Trevor is not willing to maintain such a state in order to retain a connection to his family. "It shuts down, it forecloses a trajectory of developing a kind of queer subjectivity or sexual subjectivity that's challenging to the heteronormative order," he explains. "And I refuse to be that way." Trevor compels us to ask what is behind such commitments to normative family units, even those that may be causing one harm. Additional research is necessary to explore why LGBTQ2+ people maintain connections to family members who limit and restrict their ability to authentically express themselves in order to expand our understanding of LGBTQ2+ familial experiences.

In this refusal is also a refusal to participate in the kind of masculinity Trevor sees among men in his family, particularly his brothers. He defines this masculinity in the following way:

It's selfishness, it's aggression, it's violence, there's a certain way of communicating that is incredibly disrespectful to other people's realities. There's a lack of empathy...It's really just a thicket of bullshit that I just need to separate myself from because I'm happier that way. It's just so fundamentally toxic.

Ultimately, Trevor has been able to dissolve the identity gaps he faced by dissolving relationships that required him to act inauthentically, and replacing them with new connections 
that make-up what he defines as a "rich alternative support system" of people he shares similar values and beliefs with. It was not until more recently that Trevor consciously tried to reconnect with his heritage by joining a Portuguese history walk in the city.

It is important to note, however, that no one else interviewed here has chosen to disconnect from their family in a similar way. This is not to invalidate Trevor's experience or suggest that LGBTQ2+ people in similar situations should not seriously consider it, but to point out that this research does not yet suggest that this is a common response amongst this population. Most participants in this research spoke about their families in positive terms. Jorge, who has been abused and rejected by his family, maintains that his parents raised him to the best of their ability in a foreign country with very little money and education, and still hopes to reconnect with them. "I must say I don't want...this to come out in a way attacking [my] parents," he explains. It is not my intention here to evaluate how Portuguese gay men relate to their families, or suggest how others should. Instead, I hope to show that there are meaningful ways of living without retaining a connection to family members who are having a negative impact on one's life.

\section{University Bound}

For Trevor, Gilberto, and Alex, university played a significant role in the development and expression of their identities. University offered Trevor "independence and autonomy," but also proved a way to sever his connection to his roots. He explains:

My mother had a grade 8 education, so did my grandmother, they were agricultural workers in São Miguel. And my dad had some, he was a civil servant, he was the most educated person in my family. And he was highly respected because he had a bit more education than most...So for me it was, you know, going out on this other trajectory of education separates you from those roots.

Beyond the disconnection it facilitated, Trevor's undergraduate experience also allowed him the opportunity to get involved with activist efforts, further develop his interests, and meet people 
who were "on the same wavelength" that he could trust and rely on in communication that is more open than that he could have with his family.

For Gilberto, university provided a way to reconnect with an ethnic community that he had never felt very connected to beyond the occasional community event he attended with his parents. In completing his undergraduate studies in photography, Gilberto began photographing Portuguese life and community events in the city. Around the same time, he also got involved with the Portuguese community newspaper Comunidade as a photographer.

It could be the clubs, it could be the matança de porcos [traditional Açorean pork feast] that they did, it could be the park festivals that they did.

For his thesis project he produced a photographic essay entitled, "The Masculine Image" that focused on Portuguese men and how they communicated through their body language. Despite the fact that the men he photographed as part of this project seemed "completely off-limits" because they were married, and while faced with a "sort of subconscious fear" that they might strike back with a homophobic slur like "maricas," he remembers the process as "a great way for me to cruise and photograph guys that were kind of sexy." Again behind the relative safety of his camera lens, Gilberto was able to engage with the Portuguese community in new, meaningful ways while quietly introducing his sexuality into Portuguese contexts as part of his educational pursuits. He was able to effectively subvert the potential power of the goldfish bowl as well, becoming the observer rather than the observed.

Alex found that his university experience pushed his coming out process forward in a way that he had not expected. During his time as a student, a couple incidents of violent homophobia occurred on campus. A journalist for the student newspaper approached Alex, who was "comfortably out" among his peers, to get his perspective. He thought he was going to be quoted a couple times in a larger story, but the journalist was compelled by his story and wrote a 
separate piece focused on him. The story, bordering a large photograph of Alex, was seen by a distant cousin that he did not know was studying at the same school. Eventually the story made its way back to his family and, predictably, spread. “So I didn't have to worry about telling my mother's side of the family, that's how they found out, even before my mother did," he explains. This instance illustrates how challenging it was to simultaneously hide one's sexuality in certain contexts while openly expressing it in others. While Alex could control the ways he presented himself around his family, it was not possible to limit the spread of news of how he was openly identifying at university.

It is not clear from this research if there is a strong correlation between Portuguese homosexual folk and educational achievement at a university level. It is notable that three of the five participants included here attended university as young adults at a time when educational achievement in the city's Portuguese community remained relatively low. It is possible that universities were perceived to be a place of refuge where participants could find a greater level of acceptance among more liberal-minded individuals. Such a trend was not identified among this population elsewhere prior to this research, and was only uncovered after interviews were collected. Future research should ask whether a connection between Portuguese LGBTQ individuals and university education occurs on a larger scale, and move to uncover what motivates it, and what effects it may have. It is also possible that sampling techniques used here attracted highly educated individuals who are more connected and may be more receptive to academic research.

\section{'Portuguese is many different things'}

What is common amongst all of these experiences is an element of labour and intention in carving out a new way of living that does not require the continued invisibility of one's 
sexuality. There is a level of physical and emotional work involved in engaging with communities where one does not necessarily feel welcome and disconnecting from others, forming new relationships and redefining existing ones, and cultivating support groups and new networks. Such a project for participants included here resulted in the ability to enact an identity that is more true to that which resides in the personal frame of identity but has been continually pushed into invisibility, and the opportunity to place oneself relationally and communally with people who will support such a project.

One's ethnicity, like one's sexuality, remains a permanent piece of an identity, and thus difficult to ignore. Not one participant expressed a current desire to reject their ethnicity, even if they rejected certain beliefs and practices that have become synonymous with the Portuguese in Toronto for them, or previously felt that they had to. Each continue to be Portuguese in different ways, whether that be as simple as spending Sundays with one's aging Portuguese parents, as Gilberto does, insisting on using the language whenever possible, as Alex does, or attending community events and advocating for LGBTQ rights and acceptance within it, as Jorge does. In some cases, an identity that is distinctly Portuguese and homosexual emerges, where both sides of an identity are called upon to work in tandem, as with the members of Arco-Iris, or even in participating in this research. Trevor sums it up this way:

Portuguese is many different things. I can create a different way of being Portuguese. I can be Queer Portuguese. 


\section{Conclusion}

Using the Emanuel Jaques murder and the moral panic that followed as a window into a particular community at a particular moment in time has revealed several insights about what it meant to be Portuguese and gay in Toronto in the 1970s and 1980s. The homophobia it brought to the streets of the city was already active in Toronto's Portuguese community, enforcing a state of homosexual invisibility and defining homosexualities in negative terms. Participants interviewed here felt this homophobia and the pressures it exuded in several different ways. Homophobic attitudes present in society-at-large and misguided church teachings filtered through the Portuguese community and participants' families to then be struggled with largely in isolation and internally until participants were able to connect with other LGBTQ2+ folk. The impact of these attitudes varied in severity depending on a participants' proximity to the Portuguese community and predominantly Portuguese neighbourhoods, family life, ability to

pass as heterosexual, social class, access to higher education, and access to other LGBTQ2+ folk. At certain moments, each participant was implicitly or explicitly pushed to make their sexualities invisible and limit the ways their sexual identity was enacted, surveying their own actions to ensure that such a sexuality could not be discerned by outside observers.

This required participants to adopt identity gaps that hid the nature of their sexualities in the personal frame of their identity. While some may dismiss this as merely a common part of the young gay experience without much substance, research shows that the implications of such gaps are significant and go beyond those recounted here, like compromising on one's education or love life (as was the case with Gilberto and Jorge, respectively). Jung and Hecht (2004) have found high negative correlations between personal-enacted identity gaps and personal-relational identity gaps, like those observed here, and communication outcomes, including communication 
satisfaction and feeling understood. By applying their conceptualization of identity gaps to existing studies, the authors conclude that identity gaps may also be associated with psychological and behavioural issues. Indeed, Jung et al. (2007) have found personal-enacted identity gaps to have strong direct effects on depression levels among international students at a large northeastern university in the United States. It is thus crucial that we push back against cultural environments that encourage the formation of identity gaps, instead allowing individuals to express a self that aligns with their view of themselves. In practice, this means fostering an environment that is welcome to and receptive of all LGBTQ2+ identities.

\section{Limitations}

This work is limited by a relatively narrow focus and small sample size. While focusing on the Jaques murder and the ' 70 s and ' 80 s is useful in providing us with depth and specificity, the insights uncovered here cannot all be extended into our contemporary moment. This examination also does not include the undoubtedly illuminating voices of women and trans individuals. The voices that are included are those who openly identify as part of the LGBTQ2+ community, and not those who may still feel pushed into a state of invisibility. Ultimately, the experiences shared by participants included here are invaluable but cannot be generalized or understood as representative of the Portuguese LGBTQ experience in the city at this time. It is thus necessary that they are understood as explorations into this community, and as new discoveries rather than final conclusions. However, it is likely that the main themes encountered in this work can be found in the stories of others in this population and thus can be used to inform or support future hypotheses or research designs. 


\section{Future Directions}

This research should be extended to include more voices from the Portuguese LGBTQ community in Toronto, and need not focus solely on the murder of Emanuel Jaques. While certainly an impactful moment in the lives of a number of Toronto's Portuguese, it should not overshadow the wide variety of impactful experiences in the lives of Toronto's Portuguese LGBTQ population, both positive and negative — some of which are outlined in this work, including the HIV/AIDS crisis. Themes of family and visibility/invisibility are likely to be prevalent in many stories to be uncovered in this population, and should thus be further developed. It would undoubtedly be useful to extend these examinations into the adult lives of individuals in this population as well, asking, perhaps, how their upbringing in the Portuguese community has affected their work-life, sexual or romantic relationships, or political engagement. A thorough examination of why some Portuguese LGBTQ people retain a connection to family members who continue to reject them would introduce nuance to the contention that the family is the most important social institution in the lives of Portuguese immigrants in Canada. Such an examination may ask how a LGBTQ person's social and economic standing contributes to their perceived reliance on a traditional family structure. It should also question how the traditional family unit in the Portuguese community as outlined here has evolved since the " $70 \mathrm{~s}$ and ' $80 \mathrm{~s}$, and consider the implications of any difference in the lives of Portuguese LGBTQ people currently coming of age.

Although young Portuguese LGBTQ people in the city today may not be able to articulate if and how the Emanuel Jaques murder and panic that followed impacted their own lives, it would certainly be fruitful to explore how the cultural environments they face both inside and outside of the family compare to that which participants here describe. This work should also 
consider how normative gender roles and expectations are pushed on this population today. Ultimately, a more filled out body of work focused on the Portuguese LGBTQ experience in Toronto would go great lengths in defining the struggles and successes of this community for the Portuguese themselves to learn from, as well as other scholars researching the intersection of sexuality, gender and ethnicity in diasporic communities in the city.

\section{Making Space}

This work adds an important element to scholarship focused on the Emanuel Jaques murder by grounding it in the previously unheard experiences of some of those who were present and implicated in the moral panic as members of both the Portuguese and LGBTQ2+ communities. This expands our understanding of the murder and the moral panic that followed by showing how such a panic affected individuals caught between two of its sides. Jorge, Adriano and Gilberto were not immune from the fears activated by the murder and represented in the panic, and the narratives put forth in the "clean-up" campaign that painted homosexuals and Yonge Street as a serious threat. These fears were internalized, and participants questioned if they themselves were in danger because of their sexualities, or even at risk of becoming like the men who killed Jaques. It also heightened anxieties regarding the possibility that the notion that homosexual men pose a threat to children could be applied to them. For Jorge, the murder proved to be a source of guilt tied to his own childhood sexual abuse that was pushed into silence for many years. While these particular men were not outwardly classified as folk devils in the panic because of their practiced ability to pass as heterosexual, they were nonetheless affected by its might. Alex and Trevor, who were both too young to remember the summer of ' 77 with clarity, offer useful insight into the legacy of the murder and panic. Alex illustrates for us how Portuguese gay youth confronted the threat to children argument with one another years after the 
murder, and Trevor reminds us to recall the panic through a critical lens, sensitive to the homophobia present within it and that it inspired. Ultimately, this work begins the discovery process in detailing how Portuguese LGBTQ2+ folk experienced the Jaques murder and the panic it ignited, as well as how they recall it today.

Each participant has discovered ways to live more openly with their sexualities, and most have been able to do so while retaining a connection to their Portuguese heritage. For some, this process required the cautious revealing of their sexualities to those around them over a period of several years. Others felt compelled to disconnect themselves from problematic relationships and systems of belief that restricted and rejected their sexualities. All participants point to the formation of connections with other LGBTQ2+ people aiding in their own development, whether that be in formal or informal groups and organizations, or through friendships and romantic relationships. This points to the important role that LGBTQ2+ connections and support networks can play in the lives of the community's members, and shows us how a Portuguese identity can publicly coexist with a homosexual one. While we cannot ensure that groups like the one Alex and Adriano were a part of organically form wherever LGBTQ2+ people are, we can continue to support the existence and formation of accessible groups and collectives that welcome individuals who may not otherwise have such a support network. On a local level, this could mean encouraging and supporting community organizations that support LGBTQ2+ youth and Gay-Straight Alliances in Toronto schools. Additional research is needed to define how important it is for these connections to form, where they may be best encouraged, and what their absence may result in in the lives of LGBTQ2+ people.

On a broader scale, this work engages with scholarship surrounding both the Portuguese and LGBTQ2+ communities in Toronto. It starts to fill a gap in both of these bodies of work 
where a complete lack of research into this particular population once existed, and begins to identify some of the themes common in their experiences. The perspectives shared by participants included here are informed by both histories, and begin to show us the effects of their convergence. It provides a basis for understanding this moment of time in a new way, and sheds new light on how those affected responded through the careful communication of their own identities. This study also adds to the body of literature utilizing the Communication Theory of Identity in considering how LGBTQ2+ individuals reconcile a marginalized sexual or gender identity with their ethnic roots. Most importantly, however, it carves out a space for the perspectives of Portuguese LGBTQ individuals in Toronto to be reintroduced into a history that they were no doubt present for but one that had not previously sought to include their voices. 


\section{Appendix A: Interview Guide}

Each interview was separated into four parts, guided by open-ended questions with additional prompts prepared in advance and used where needed. The interview guide used is included here.

\section{Today}

- What is it like being Portuguese and gay in Toronto today?

o Where do you find a sense of community?

o How do you connect with other Portuguese people? LGBTQ people?

o How does your sexuality affect your relationship with your family?

\section{Growing Up}

- Were you born in Portugal? (If yes): When did you move to Canada?

o (If no): When did your parents move to Canada?

- Can you tell me a bit about what growing up in the Portuguese community in Toronto was like?

o What made it unique? Challenging? Beneficial?

o Where did you spend your time? With whom?

- What were some of the beliefs and values you grew up with?

o Where/who did you learn them from?

o Were they valuable to you?

- How did you fit in, or not, among other Portuguese in the city?

- Who were your role models and how did they affect how you imagined yourself as an adult?

o What made them good role models?

- What were the attitudes surrounding homosexuality and gender in the Portuguese community at this time?

o How did they influence your own understanding of homosexuality and gender?

o Were there any LGBTQ folk living openly in the community? How were they treated?

- Did you feel any pressures to act a certain way? What were they? Where did they come from?

o How did you deal with them?

o Did you ever feel like you were pretending to be someone you weren't?

o What did it mean to be yourself? 


\section{The Jaques Murder}

- Do you remember where you were when the news of Emanuel Jaques' kidnap first broke?

o What was this time like?

o How old were you?

o What part of the city did you live in at this time?

- How did your family react to the news that Jaques was raped and murdered?

o How did you react?

- What did you think about the Portuguese response to the murder?

o Did you find it to be homophobic?

- It is clear that the murder had a significant impact in the community. How did it affect your life in the short- and long-term?

o How did it affect the way you thought of yourself? Other LGBTQ people?

o How did it affect your relationships with family/partners/friends/co-workers?

\section{Sexuality}

- How did you come to understand your own sexuality?

o What was that like?

o How did you express your sexuality?

o Did the Jaques murder change the ways you could express your sexuality?

- Where could you feel most comfortable being yourself?

o With whom?

- Who could you turn to for support?

o What made them a good support system?

\section{Looking Forward}

- What might you say to young Portuguese LGBTQ folk growing up in this community today? 


\section{Appendix B: Coding Subcategories Defined}

\section{Personal}

Self-Images \& Concepts: How participants see and describe themselves.

Beliefs \& Convictions: Values and points of view participants express.

\section{Enacted}

Learning: Efforts to achieve new skills or knowledge, including formal and informal modes of education.

Community Engagement: Efforts to connect with particular communities, including Portuguese and LGBTQ2+ communities.

Cultivating: Efforts to build new support systems and new relationships.

Expressing Sexuality: How sexuality is communicated through external physical acts and behaviour.

Expressing Gender: How gender is communicated through external physical acts and behaviour.

\section{Relational}

Attitudes Surrounding Homosexuality: Narratives, representations, and sentiments participants observed relating to homosexuality.

Family: Interactions and links to intermediate and extended family members.

Friends \& Partners: Interactions and links to platonic friends and romantic partners.

Gender Roles \& Relations: Narratives, representations, and sentiments participants observed relating to gender.

Trauma: Experiences of real or perceived violence and abuse.

\section{Communal}


Portuguese Community; LGBTQ2+ Community; and Religion \& the Church: Shared values, knowledge and notable experiences participants observed in each respective community. 


\section{References}

Anderson, G.M. \& D. Higgs. 1976. A Future to Inherit: Portuguese Communities in Canada. Toronto, ON: McClelland and Stewart Limited.

Beddoes, D. (1977, August 5). In sorrow and anger. The Globe and Mail, p. 8.

Beddoes, D. (1977, August 10). Gays on guilt: Blame media. The Globe and Mail, p. 8.

Berger, P. \& Luckman, T. (1966). The social construction of reality: A treatise in the sociology of knowledge. New York, NY: Anchor Books.

Bloemraad, I. (2009). Invisible No More? Citizenship and Politics among Portuguese Canadians. In Teixeira, C. \& Da Rosa, V. M. P. (Eds.) The Portuguese in Canada: Diasporic Challenges and Adjustment (p. 161-188). Toronto, ON: University of Toronto Press.

Brazao, D. (1977, August 4). Yonge St. is for kids too, 12-year-old tells Davis. The Toronto Star, p. A1.

Brock, D. R. (1998). Making work, making trouble: Prostitution as a social problem. Toronto: University of Toronto Press.

Cohen, S. (1972). Folk Devils and Moral Panics: The Creation of the Mods and Rockers. London: MacGibbon \& Kee.

De Sa, A. (2013). Kicking the Sky. Toronto: Doubleday Canada.

Faulkner, S. L. \& Hecht, M. L. (2011). The negotiation of closetable identities: A narrative analysis of lesbian, gay, bisexual, transgendered queer Jewish identity. Journal of Social and Personal Relationships, 28 (6), 829-847. doi:10.1177.0265407510391338

Ferguson, E. (1964). Newcomers in transition: A project of the International Institute of Metropolitan Toronto, 1962-1964. Toronto, ON: International Institute of Metropolitan Toronto. 
Fernandes, G. (2010). Beyond the 'Politics of Toil': Collective mobilization and individual activism in Toronto's Portuguese community, 1950s-1990s. Urban History Review; Toronto, 39 (1), 59-72, 80.

Fileborn, B. (2016) Participant recruitment in an online era: A reflection on ethics and identity. Research Ethics, 12 (2), 97-115.

Garland, D. (2008). On the concept of moral panic. Crime, Media, Culture: An International Journal, 4 (1), 9-30.

Gergen, K. J. (1999). Invitation to social construction. Thousand Oaks, CA: Sage Publications.

Giles, W. M. (2002). Portuguese Women in Toronto: Gender, Immigration, and Nationalism. Toronto, ON: University of Toronto Press.

Goode, E., \& Ben-Yehuda, N. (1994). Moral panics: Culture, politics, and social construction. Annual Review of Sociology, 20, 149-171.

Hacking, I. (1999). The social construction of what? Cambridge, MA: Harvard University Press.

Higgs, D. (1982). The Portuguese in Canada. Ottawa, ON: Canadian Historical Association.

Homosexual backflash feared (1977, August 3). The Toronto Star, p. A3.

Hoshowsky, R. J. (2017). Outraged: The murder of shoeshine boy Emanuel Jaques. Canada: RJ Parker Publishing.

Jung, E. \& Hecht, M. L. (2004). Elaborating the Communication Theory of Identity: Identity gaps and communication outcomes. Communication Quarterly, 52 (3), 265-283. doi:10.1080/01463370409370197

Jung, E. \& M.L. Hecht, B.C. Wadsworth (2007). The role of identity in international students' psychological well-being in the United States: A model of depression level, identity gaps, 
discrimination, and acculturation. International Journal of Intercultural Relations, 31, 605-524. doi:10.1016/j.ijintrel.2007.04.001.

Kenedy, R. A. (2009). Arco-Iris: understanding the collective identity of lesbian-gay-bisexualtransgendered Portuguese Canadian community groups in Toronto. Portuguese Studies Review, 17 (2), 45-61.

Kinsman, G. (1996). The regulation of desire: Homo and hetero sexualities (2nd ed.). Montreal, QC: Black Rose Books Ltd.

Kuckartz, U. (2013). Three basic methods of qualitative text analysis. Qualitative Text Analysis: A Guide to Methods, Practice \& Using Software (p. 65-120). London: SAGE Publications Ltd.

Leech, B. L. (2002). Asking questions: Techniques for semistructured interviews. Political Science and Politics, 35 (4), 665-668. doi:10.1017/S1049096502001129

McCaskell, T. (2016). Queer progress: From homophobia to homonationalism. Toronto: Between the Lines.

Nash, C. (2003). Toronto's gay ghetto: Politics and the disciplining of identity and space (19691982). (Unpublished doctoral thesis). Queen's University, Kingston, ON.

Nash, C. (2014). Consuming sexual liberation: Gay business, politics, and Toronto's Barracks bathhouse raids. Journal of Canadian Studies, 48 (1), 82-105.

Newman, Z. (2002). Whitening the inner city: The containment of Toronto's degenerate spaces and the production of respectable subjects. (Unpublished doctoral dissertation). University of Toronto: Toronto, ON.

Newman, Z. (2016). The spectacle of public sex(uality): Media and State surveillance of gay men in Toronto in the 1970s. In Van der Muelen, E. \& Heynen, R. (Eds.) Expanding the 
Gaze: Gender and the Politics of Surveillance (p. 213-239). Toronto: University of Toronto Press.

Ng, Y. (1981). Ideology, media and moral panics: An analysis of the Jaques murder (Unpublished master's thesis). University of Toronto: Toronto, ON.

Norris, D. (1977, July 30). Toronto boy, 12 missing. The Toronto Star, p. A1.

Nunes, F. (1986). Problems and Adjustments of the Portuguese Immigrant Family in Canada. Porto: Secretaria de Estado das Comunidades Portuguesas.

Ornstein, O. (2000). Ethno-racial inequality in the City of Toronto: An Analysis of the 1996 census. Report prepared for the Access and Equity Unit, City of Toronto. Toronto, ON: City of Toronto.

Pharr, S. (1997). Homophobia: A weapon of sexism (2nd ed.). Little Rock, AR: Chardon Press. Pereira, D. (2014). Labored masculinity: Class, gender, and the educational choices and attitudes of young men of Portuguese ancestry in Toronto. InterDISCIPLINARY Journal of Portuguese Diaspora Studies, 3 (2), 387-408.

Plummer, K. (2001). Truth, value and memory in life stories. Documents of Life2 (p. 233-254). London: Sage Publications Ltd.

Porambo, R. (1977, August 4). The neighbors march for Manuel. The Globe and Mail, p. 4.

Rocha-Trinidade, M.B. (2009). The Portuguese diaspora. In Teixeira, C. \& Da Rosa, V. M. P. (Eds.) The Portuguese in Canada: Diasporic Challenges and Adjustment (p. 18-41). Toronto, ON: University of Toronto Press.

Rogers, B. (1977, August 9). 15,000 march on City Hall, Legislature over boy's slaying. The Globe and Mail, p. 1. 
Ross, B. (1990). The house that Jill built: Lesbian feminist organizing in Toronto, 1976-1980. Feminist Review, 35, 75-91.

Sardinha, J. (2011). Portuguese-Canadian Emigrant Descendents in Multicultural Canada: Ambiguous Identity in a Sure-Footed Nation or Cultural Awareness in an Uncertain Country? International Migration \& Integration, 12, 371-389.

Smith, M. (1999). Lesbian and gay rights in Canada. Toronto: University of Toronto Press.

Sydor, A. (2013). Conducting research into hidden or hard-to-reach populations. Nurse Researcher, 20 (3), 33-37.

Thomas, G. J. (1977, August 1). Shoeshine boy, 12, found slain. The Toronto Star, p. A1.

Thomas, G. J. \& B. Graham. (1977, August 2). Boy was drowned in a sink. The Toronto Star, p. A1.

Woodley, X. M. \& Lockard, M. (2016). Womanism and snowball sampling: Engaging marginalized populations in holistic research. The Qualitative Report, 21 (2), 321-329. 